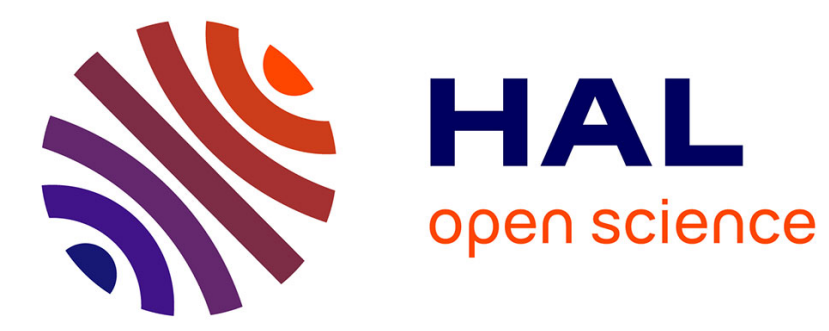

\title{
The effect on the intestine of some fungal toxins: The Trichothecenes
}

Philippe Pinton, Laurence Guzylack-Piriou, Martine Kolf-Clauw, Isabelle P. Oswald

\section{- To cite this version:}

Philippe Pinton, Laurence Guzylack-Piriou, Martine Kolf-Clauw, Isabelle P. Oswald. The effect on the intestine of some fungal toxins: The Trichothecenes. Current Immunology Reviews, 2012, 8 (3), pp.193-208. 10.2174/157339512800671967 . hal-02644112

\section{HAL Id: hal-02644112 \\ https://hal.inrae.fr/hal-02644112}

Submitted on 28 May 2020

HAL is a multi-disciplinary open access archive for the deposit and dissemination of scientific research documents, whether they are published or not. The documents may come from teaching and research institutions in France or abroad, or from public or private research centers.
L'archive ouverte pluridisciplinaire $\mathbf{H A L}$, est destinée au dépôt et à la diffusion de documents scientifiques de niveau recherche, publiés ou non, émanant des établissements d'enseignement et de recherche français ou étrangers, des laboratoires publics ou privés. 


\title{
The Effect on the Intestine of Some Fungal Toxins: The Trichothecenes
}

\author{
P. Pinton ${ }^{1}$, L. Guzylack-Piriou ${ }^{1}$, M. Kolf-Clauw ${ }^{2}$ and I.P. Oswald ${ }^{*, 1}$ \\ ${ }^{I}$ INRA, UMR1331, Toxalim, Research Centre in Food Toxicology, F-31027 Toulouse, France \\ ${ }^{2}$ Université de Toulouse, ENVT, INP, F- 31076 Toulouse, France
}

\begin{abstract}
The intestinal tract represents the first barrier to ingested chemicals or food contaminants and is also the first line of defense against intestinal infection. Because of their location, intestinal epithelial cells could be exposed to high doses of food contaminants. Among natural food contaminants, mycotoxins are regarded as an important risk factor for human and animal health as up to $25 \%$ of the world's crop production may be contaminated. The Fusarium genus produces high quantities of toxins (fusariotoxins) in temperate northern countries (North America, Europe or Asia) and the trichothecenes are the most prevalent toxin detected. An increasing number of studies suggest that intestinal epithelial cells are important targets for mycotoxins and in humans, various adverse digestive symptoms are observed on acute exposure. In animals, trichothecenes induce pathological lesions, including necrosis of the intestinal epithelium. They affect the integrity of intestinal epithelium through alterations in the barrier function, cell morphology and differentiation. Moreover these toxins modulate the activity of intestinal epithelium in its role in immune responsiveness. They affect the cytokine production by intestinal or immune cells and are supposed to interfere with the cross-talk between epithelial cells and other intestinal immune cells. This review summarizes our current knowledge of the effects of a class of mycotoxins, the trichothecenes, on the intestine.
\end{abstract}

Keywords: Barrier-function, food-contaminant, immune response, intestinal lesions, intestine, mycotoxins.

\section{INTRODUCTION}

The intestinal epithelium is a single layer of cells lining the gut lumen that acts as a selective filter, allowing the translocation of essential dietary nutrients, electrolytes, and water from the intestinal lumen into the circulation. It also constitutes the largest and most important barrier to prevent the passage from the external environment into the organism of harmful intraluminal substances, including foreign antigens, microorganisms, and their toxins [1]. The establishment of the epithelial monolayer by intestinal epithelial cells is dependent upon a considerably high degree of intracellular and intercellular organization. Within each epithelial cell, structural integrity is maintained by the presence of a complex cytoskeletal network of microfilaments playing a crucial role in maintaining cellular polarity and in supporting points of cell-cell contact. The interaction and contact between adjacent intestinal epithelial cells of the monolayer is mediated by distinct junctions including tight junctions, desmosomes and adherens junctions [2]. The functions as a selective permeable barrier place the mucosal epithelium at the centre of interactions between the mucosal immune system and luminal contents, which includes dietary antigens and microbial products [3]. The intestine is a privileged immune site where immunoregulatory mechanisms simultaneously defend the body against pathogens but also preserve tissue homeostasis to avoid immune-mediated pathology in response to environmental challenges. Following the ingestion of contaminated food or feed, intestinal epithelial cells may be

\footnotetext{
*Address correspondence to this author at the INRA-Laboratoire de Pharmacologie-Toxicologie, 180 chemin de Tournefeuille BP3, 31931 Toulouse Cedex 9, France; Tel: +33 561285480;

E-mail : isabelle.oswald@toulouse.inra.fr
}

exposed to high concentrations of toxicants, potentially affecting intestinal functions [4].

Mycotoxins are structurally diverse fungal metabolites that can contaminate a variety of dietary components consumed by animals and humans. It is estimated that $25 \%$ of the world crop production is contaminated by mycotoxins during the pre-harvest period, transport, processing or storage [5]. The major mycotoxin-producing fungal genera are Aspergillus, Fusarium and Penicillium mainly producing aflatoxins, zearalenone, trichothecenes, fumonisins, ochratoxins and ergot alkaloids. Among the mycotoxins produced by the Fusarium genus, the wide family of trichothecenes is extremely prevalent. These compounds are commonly found on cereals such as wheat, rye, barley, oats and corn grown in the temperate regions of Europe, America and Asia [6-8]. Furthermore, these toxins are resistant to milling, processing and heating and, therefore readily enter the food chain [9]. Intoxications following the consumption of foodstuffs contaminated with trichothecenes have occurred in both humans and animals, with large numbers of people and livestock being affected [8]. They represent the most diverse chemical group of all the mycotoxins and their molecular weights range between 200-500 Da. All trichothecenes possess a sesquiterpenoid structure, contain a common 12,13-epoxytrichothene group responsible for their cytotoxicity, and a 9,10-double bond with various side chain substitutions. Depending on the presence of a macrocylic ester or an ester-ether bridge between C-4 and C-15, trichothecenes are classified as macrocylic or nonmacrocyclic [6]. The non-macrocylic trichothecenes constitute two groups: type $\mathrm{A}$, which have a hydrogen or ester type side chain at the C-8 position, and include T-2 toxin, HT-2 toxin, neosolaniol, and diacetoxyscirpenol (DAS), while the type B group contain a ketone and include fusarenon-X (FUS-X), nivalenol (NIV), and deoxynivalenol 
(DON) and its 3-acetyl and 15-acetyl derivates (Table 1). The number and position of the hydroxyl and acetyl-ester groups can influence the relative toxicity within eukaryotic cells. Their relative capacity to interfere with protein synthesis has been attributed to a combination of different factors: rate of transport into cells, metabolism by cytosol enzymes, changes in affinity for the active binding site or capacity to interfere with protein synthesis [7].

The intestinal tissue is the first barrier in contact with those compounds and in the literature there are reports of some aspects of the impact of trichothecene ingestion, considered as a major risk of exposure to mycotoxin. This review summarizes the consequences of exposure to trichothecenes on histopathological intestinal lesions, on the potential disruption of the intestinal barrier function and on the active role of the intestinal mucosa in immune responsiveness.

\section{INTESTINAL LESIONS INDUCED BY TRICHOTHECENES}

The indications of acute and chronic trichothecenes toxicity include digestive problems, reduced food intake and possibly food refusal in all species, but with with different sensitivities. The most sensitive species to acute toxicity by trichothecenes are pig, cat, rat and guinea pig, whereas poultry and mice are the most resistant species. This differential sensitivity can in part be explained by the toxicokinetics. As far as DON is concerned, the animal species can be ranked in the following order: pigs $>$ mice $>$ rats $>$ poultry $\approx$ ruminants [7]. The lymphoreticular system and the gut are identified as trichothecene targets. Histological alterations in lymphoid tissues consist of necrosis and lymphocytolysis in the spleen, thymus, bone marrow, lymph nodes and Peyer's patches. This current review will focus on the lesions of the mucosa of the digestive tract caused by trichothecenes type A and type B in various animal species, either as pure toxins, mixtures of toxins, or dietary mixtures containing Fusarium cultures. They involve all the parts of digestive tract, after acute or chronic exposure, whatever the route of administration. No particular intestinal segment appears more sensitive than others to trichothecenes $[10,11]$.

We will focus on intestinal lesions, which are more severe and more extended with type A trichothecenes compared to type B trichothecenes. T2-toxin, followed by DAS, is the most toxic trichothecene in experimental animals as well as in livestock, after both acute and chronic dietary exposure.

\subsection{Intestinal Lesions Upon Acute Exposure to Trichothecenes}

Acute exposure induces very similar clinical signs and pathological lesions in all animal species, including necrosis of lymphoid tissues and of the intestinal epithelium (Table 2). Congestive to fibrino-necrotic intestinal inflammation characterize trichothecene acute toxicity in experimental animals and in livestock. Histological analyses show necrosis and degenerative mucosal cells in the jejunum and ileum, in the villi and crypts, with pyknotic and karyorrhexis structures. In pigs, chicken and rodents following high exposure to T-2 toxin or DAS, the intestinal mucosa may hemorrhage and blood can be recovered in the digestive tract [12-18].

\subsubsection{Rodents}

Intestinal necrosis, frequently extended and perforative, appears independently of the route of administration for

Table 1. Chemical Structure of Type A and B Trichothecenes

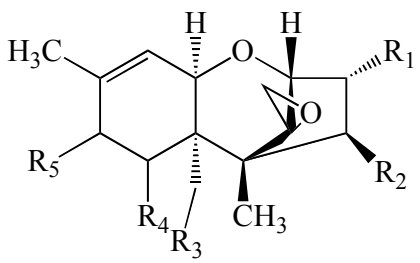

\begin{tabular}{|c|c|c|c|c|c|}
\hline Trichothecenes & R1 & $\mathbf{R} 2$ & $\mathbf{R 3}$ & R4 & R5 \\
\hline \multicolumn{6}{|l|}{ Type A } \\
\hline $\mathrm{T}-2$ Toxin & $\mathrm{OH}$ & OAc & OAc & $\mathrm{H}$ & $\left(\mathrm{CH}_{3}\right)_{2} \mathrm{CHCH}_{2} \mathrm{COO}$ \\
\hline HT-2 Toxin & $\mathrm{OH}$ & $\mathrm{OH}$ & OAc & $\mathrm{H}$ & $\left(\mathrm{CH}_{3}\right)_{2} \mathrm{CHCH}_{2} \mathrm{COO}$ \\
\hline DAS & $\mathrm{OH}$ & $\mathrm{CH}_{3} \mathrm{COO}^{-}$ & $\mathrm{CH}_{3} \mathrm{COO}$ & $\mathrm{H}$ & $\mathrm{H}$ \\
\hline Nivalenol & $\mathrm{OH}$ & $\mathrm{OH}$ & $\mathrm{OH}$ & $\mathrm{OH}$ & $\mathrm{O}$ \\
\hline FUS-X & $\mathrm{OH}$ & OAc & $\mathrm{OH}$ & $\mathrm{OH}$ & $\mathrm{O}$ \\
\hline 15 acetyl-deoxynivalenol & $\mathrm{OH}$ & $\mathrm{H}$ & OAc & $\mathrm{OH}$ & $\mathrm{O}$ \\
\hline 3 acetyl-deoxynivalenol & OAc & $\mathrm{H}$ & $\mathrm{OH}$ & $\mathrm{OH}$ & $\mathrm{O}$ \\
\hline
\end{tabular}


Table 2. Intestinal Lesions Reported After Trichothecene Exposure

\begin{tabular}{|c|c|c|c|c|}
\hline $\begin{array}{l}\text { Animal } \\
\text { Species }\end{array}$ & Toxin & $\begin{array}{l}\text { Concentration* and } \\
\text { Exposure }\end{array}$ & Intestinal Lesions & References \\
\hline \multicolumn{5}{|c|}{ Intestinal lesions induced by acute exposure to trichothecenes } \\
\hline \multirow[t]{7}{*}{ Rodents } & DON & Mice, oral, $100 \mathrm{mg} / \mathrm{kg}$ bw & \multirow{2}{*}{$\begin{array}{l}\text { Severe necrosis of the crypts epithelial cells. Congestion in lamina propria of } \\
\text { the villi. }\end{array}$} & {$[22]$} \\
\hline & $15-\mathrm{a}-\mathrm{DON}$ & Mice, oral, $40 \mathrm{mg} / \mathrm{kg}$ bw & & {$[22]$} \\
\hline & \multirow[t]{2}{*}{$\mathrm{T} 2$ toxin } & $\begin{array}{c}\text { Rabbit, oral, } \\
1-15 \mathrm{mg} / \mathrm{kg} \mathrm{bw} \\
\text { Rat, oral, } 3 \& 5 \mathrm{mg} / \mathrm{kg} \mathrm{bw}\end{array}$ & $\begin{array}{l}\text { Acute catarrhal gastroenteritis, necrosis of lymphoid cells of the } \\
\text { gastrointestinal mucosa } \\
\text { Necrosis of lymphoid cells throughout the lamina propria, mucosal ulceration }\end{array}$ & {$[23]$} \\
\hline & & Rat, oral, $25 \mathrm{mg} / \mathrm{kg}$ bw & Necrosis; duodenal villi shorter and blunted & {$[26]$} \\
\hline & \multirow[t]{2}{*}{ FUS-X } & $\begin{array}{l}\text { Mice, oral, } \\
\text { LD } 504.5 \mathrm{mg} / \mathrm{kg} \text { bw }\end{array}$ & Necrosis and hemorrhage & {$[24,137]$} \\
\hline & & Rat, oral, $1.5 \mathrm{mg} / \mathrm{kg}$ bw & Apoptosis in gastric mucosa & {$[25]$} \\
\hline & DAS & $\begin{array}{l}\text { Mice, oral } \\
2-22 \mathrm{mg} / \mathrm{kg} \text { bw }\end{array}$ & Transmural multifocal necrosis at lethal doses (LD50 $15.5 \mathrm{mg} / \mathrm{kg}$ bw) & {$[19]$} \\
\hline \multirow[t]{3}{*}{ Pig } & DON & Intravenous, $0.5 \mathrm{mg} / \mathrm{kg}$ bw & No intestinal lesions. Pancreatic lesions. & [27] \\
\hline & T2-toxin & $\begin{array}{l}\text { Intravenous, } \\
0.13-3.2 \mathrm{mg} / \mathrm{kg} \text { bw }\end{array}$ & $\begin{array}{l}\text { Severe congestion and hemorrhage of jejunal and ileal mucosae; epithelial and } \\
\text { crypt cell necrosis (pyknotic nuclei and karyorrhexis) }\end{array}$ & {$[16,138]$} \\
\hline & DAS & $\begin{array}{l}\text { Intravenous, } \\
0.21-0.41 \mathrm{mg} / \mathrm{kg} \text { bw }\end{array}$ & Congestion and hemorrhage of the gastrointestinal mucosa; enterocyte damage & [18] \\
\hline \multirow[t]{5}{*}{ Poultry } & \multirow[t]{2}{*}{ T2-toxin } & \multirow[t]{2}{*}{$\begin{array}{l}\text { Broiler chickens, oral } \\
2.5 \mathrm{mg} / \mathrm{kg} \text { bw }\end{array}$} & $\begin{array}{l}\text { Atrophy of intestinal villi, necrosis of the epithelium of villi and crypts in the } \\
\text { small and large intestine }\end{array}$ & \\
\hline & & & Hemorrhage & {$[15]$} \\
\hline & \multirow[t]{2}{*}{ DAS } & \multirow[t]{2}{*}{$\begin{array}{l}\text { 1-day-old chicken, oral } \\
2.7 \mathrm{mg} / \mathrm{kg} \text { bw }\end{array}$} & $\begin{array}{l}\text { Atrophy of intestinal villi, necrosis of the epithelium of villi and crypts in the } \\
\text { small and large intestine }\end{array}$ & \\
\hline & & & Hemorrhage & [15] \\
\hline & DON & $\begin{array}{l}\text { 1-day chicken, oral } \\
35-1120 \mathrm{mg} / \mathrm{kg} \text { bw }\end{array}$ & Hemorrhage & {$[13]$} \\
\hline \multicolumn{5}{|c|}{ Intestinal lesions reported after repeated trichothecene oral administrations (dietary or gavage) } \\
\hline \multirow[t]{4}{*}{ Rodents } & \multirow[t]{3}{*}{ T2-toxin } & Mice, $20 \mathrm{mg} / \mathrm{kg}, 6$ weeks & $\begin{array}{c}\text { Reduced feed intake and average daily gain, gastric and oesophageal } \\
\text { ulcerative lesions and hyperplasia }\end{array}$ & \\
\hline & & $\begin{array}{l}\text { Mice-Rat, } \\
10-20 \mathrm{mg} / \mathrm{kg}, 2-4 \text { weeks }\end{array}$ & Hyperkeratosis of the squamous gastric mucosa & [139] \\
\hline & & $\begin{array}{l}\text { Rabbit } \\
12.5-25 \mathrm{mg} / \mathrm{kg} \text {, eight days } \\
\text { Mice, } \\
1.5-3 \mathrm{mg} / \mathrm{kg}, 16 \text { months }\end{array}$ & $\begin{array}{l}\text { Reduced feed intake } \\
\text { Subacute catarrhal gastritis; necrosis of the lymphoid cells of the intestinal } \\
\text { mucosa }\end{array}$ & {$[23,35]$} \\
\hline & NIV & $\begin{array}{l}\text { Mice, } \\
12-30 \mathrm{mg} / \mathrm{kg}, 2 \text { years }\end{array}$ & Lower incidence of amyloidosis in small intestine & {$[37]$} \\
\hline \multirow[t]{7}{*}{ Pig } & \multirow[t]{5}{*}{ T2-toxin } & $0.5-15 \mathrm{mg} / \mathrm{kg}, 3$ weeks. & Reduced feed intake. No lesion & [40] \\
\hline & & $8-10 \mathrm{mg} / \mathrm{kg}, 4$ weeks. & No lesion & {$[39,140]$} \\
\hline & & $1-8 \mathrm{mg} / \mathrm{kg}, 8$ weeks. & Reduced feed intake during the first week. No lesion & \multirow[t]{3}{*}{ [16] } \\
\hline & & $12 \mathrm{mg} / \mathrm{kg}, 2-7$ months & No change in feed intake. Congestion and fibrinous erosions of mucosae & \\
\hline & & $16-32 \mathrm{mg} / \mathrm{kg} ; 2-4$ days & Feed refusal & \\
\hline & \multirow[t]{2}{*}{ DAS } & $2-9 \mathrm{mg} / \mathrm{kg}, 9$ weeks & $\begin{array}{l}\text { Reduced feed intake and average daily weight. Hyperplasia of the } \\
\text { glandular and epithelial cells in the small intestine mucosa }\end{array}$ & \multirow[t]{2}{*}[17]{} \\
\hline & & $10 \mathrm{mg} / \mathrm{kg}, 2-4$ days & Feed refusal & \\
\hline
\end{tabular}




\begin{tabular}{|c|c|c|c|c|}
\hline $\begin{array}{l}\text { Animal } \\
\text { Species }\end{array}$ & Toxin & $\begin{array}{c}\text { Concentration* and } \\
\text { Exposure }\end{array}$ & Intestinal Lesions & References \\
\hline \multirow[t]{3}{*}{ Pig } & \multirow[t]{3}{*}{ DON } & $0.75-4.2 \mathrm{mg} / \mathrm{kg}, 3-5$ weeks. & Edema and congestion & [141-143] \\
\hline & & $0.7-5.8 \mathrm{mg} / \mathrm{kg}, 4$ weeks. & $\begin{array}{l}\text { Slight to moderate inflammation and congestion of intestinal mucosa. } \\
\text { Slight to moderate degenerescence of lymphoid cells in Peyer's patches and } \\
\text { in lymph nodes }\end{array}$ & [41] \\
\hline & & $\begin{array}{c}4 \mathrm{mg} / \mathrm{kg} \\
2-3 \mathrm{mg} / \mathrm{kg}, 4 \text { weeks }\end{array}$ & $\begin{array}{l}\text { Corrugations in the fundic region (stomach) } \\
\text { Corrugations in jejunum }\end{array}$ & $\begin{array}{c}{[42]} \\
\text { Kolf-Clauw } \\
\text { (personal obs) }\end{array}$ \\
\hline \multirow[t]{7}{*}{ Poultry } & \multirow[t]{2}{*}{ T2-toxin } & $\begin{array}{l}\text { Young broilers, } \\
\text { gavage, } 14 \text { days } \\
1.5-3 \mathrm{mg} / \mathrm{kg} \text { bw/day }\end{array}$ & $\begin{array}{l}\text { Necrosis of intestinal epithelium in villi and crypts and of lamina propria } \\
\qquad \text { lymphocytes } \\
\text { Reduced verage daily weight gain }\end{array}$ & {$[43]$} \\
\hline & & Turkey, $1 \mathrm{mg} / \mathrm{kg}, 32$ days & Shorter and thinner villi in jejunum & {$[44]$} \\
\hline & \multirow[t]{2}{*}{ DAS } & $\begin{array}{l}\text { Young broilers, } \\
\text { gavage, } 14 \text { days } \\
2.5-3.5 \mathrm{mg} / \mathrm{kg} \text { bw/day }\end{array}$ & $\begin{array}{l}\text { Necrosis of intestinal epithelium in villi and crypts and of lamina propria } \\
\qquad \text { lymphocytes } \\
\text { Reduced average daily weight gain }\end{array}$ & {$[43]$} \\
\hline & & Turkey $1 \mathrm{mg} / \mathrm{kg}, 32$ days & Shorter and thinner villi in jejunum & [44] \\
\hline & DON & $\begin{array}{l}\text { Broilers, } 5 \mathrm{mg} / \mathrm{kg}, 3 \text { weeks } \\
\text { Broilers, } 10 \mathrm{mg} / \mathrm{kg}, 6 \text { weeks }\end{array}$ & $\begin{array}{l}\text { Shorter and thinner villi in duodenum } \\
\text { Shorter and thinner villi in duodenum and jejunum }\end{array}$ & $\begin{array}{l}{[45]} \\
{[52]}\end{array}$ \\
\hline & \multirow[t]{2}{*}{ NIV } & $\begin{array}{c}\text { Young broilers } \\
3-12 \mathrm{mg} / \mathrm{kg}, 20 \text {-days }\end{array}$ & Gizzard erosions & {$[29]$} \\
\hline & & $\begin{array}{c}\text { Laying hens } \\
1-5 \mathrm{mg} / \mathrm{kg}, 50 \text { days }\end{array}$ & Slight hemorrhage in duodenum & {$[46]$} \\
\hline
\end{tabular}

Concentration are expressed as $\mathrm{mg} / \mathrm{kg}$ diet except when specified ( $\mathrm{mg} / \mathrm{kg}$ body weight).

DON, 15-acetyl-deoxynivalenol (15a-DON), T2-toxin and DAS [19-23]. In addition, intestinal hemorrhage has been described in mice with FUS-X [24]. One mechanism shown with FUS-X in the rat is the induction of apoptosis in proliferating cells with the most sensitive target being the gastric fundus [25]. In rats, $12 \mathrm{~h}$ after a single oral dose of T2-toxin at $25 \mathrm{mg} / \mathrm{kg}$, the duodenal villi were shorter and blunted, the epithelial lining segmentally ulcerated and Brunner's glands and crypts largely destroyed. Extensive apoptotic necrosis of crypt cells was described together with cellular debris and mononuclear inflammatory cells in the lamina propria [26].

\subsubsection{Pigs}

Experimental acute toxicity in pigs includes digestive symptoms with emesis starting after 2 hours (DON), 15 minutes (T2-toxin) or 20 minutes (DAS) following intravenous injection [18, 27]. In pigs, this is observed together with increased defecation followed by diarrhea. Severe congestion of jejunal and ileum mucosa was observed after intravenous administration of high doses of DAS and T2-toxin $[16,18]$. In addition to degenerative lesions in the intestinal villi and crypts, necrosis and degenerative cells were observed in lymphoid tissues: Peyer's patches, mesenteric lymph nodes, and spleen $[16,18,27]$. DON doserelated jejunal lesions were observed after a 4-hours exposure in an ex-vivo pig culture model including shortened and coalesced villi, lysis of enterocytes, and edema [28].

\subsubsection{Poultry}

NIV, T2-toxin and DAS induced gizzard erosions in poultry $[12,29]$. In 1-day-old chicks, DON at a high oral dose induced digestive hemorrhagic syndrome $[13,15]$.

\subsubsection{Humans}

It seems plausible that DON and other trichothecenes cause acute digestive symptoms in humans at high exposure. T2-toxin and related trichothecenes may have been the causative agents of the disease "alimentary toxic aleukemia", including vomiting, diarrhea, hemorrhage, leucopenia, and shock that were described in the USSR during the $2^{\text {nd }}$ world war with up to $60 \%$ mortality $[9,30,31]$. Four stages have been described in the cases of survivors: the first stage is characterized by gastroenteritis followed by bone marrow depletion (second stage). In the third stage, hemorrhage and necrosis occur all along the digestive tract. The final stage requires at least two weeks for necrotive and hemorrhage lesions, and two months for the hematological signs to resolve [30]. The cat has been described as an animal model in which to reproduce alimentary toxic aleukemia $[14,32]$.

Chinese epidemiological studies related to gastroenteritis suggest that DON may induce emesis with abdominal pain and diarrhea, headache, dizziness and fever [33]. An outbreak of gastroenteritis was also reported in 1987 among Indians consuming products made from moldy wheat containing up to $8.4 \mathrm{mg} / \mathrm{kg}$ of DON [34].

\subsection{Intestinal Lesions Upon Chronic Exposure to Trichothecenes}

Subchronic and chronic exposures induce digestive erosions in experimental animals and in livestock. The most striking clinical sign is alteration of growth performance, most often related to decreased feed intake and average daily gain, depending on the concentration in feed and the exposure time (Table 2). The reporting of intestinal lesions has been inconsistent and not systematically correlated with the clinical signs. 


\subsubsection{Rodents}

After dietary exposure to a T2-toxin contaminated diet containing up to $20 \mathrm{mg} / \mathrm{kg}$, for up to 16 months in mice and rats, ulcerative erosions of the upper digestive tract can be followed by proliferative gastric lesions causing gastric hyperkeratosis, considered as secondary to erosive lesions [23, 35-38]. In mice, after two-year exposure to NIV at 30 $\mathrm{mg} / \mathrm{kg}$ dietary concentration, the rate of mortality was reduced, partly due to decreased amyloïdosis in the small intestine. No intestinal lesions were observed after 16 months T2 toxin exposure or after 2 years NIV exposure [37, 38].

\subsubsection{Pigs}

Chronic exposure to trichothecenes via the feed decreases growth performances $[16,17,39,40]$. Radiomimetic syndrome, with mucosal and cutaneous lesions, is observed above contamination with T2-toxin and DAS higher than 5 to $10 \mathrm{mg} / \mathrm{kg}$ diet and $4 \mathrm{mg} / \mathrm{kg}$ diet respectively. Histological lesions have been described after dietary exposure as low as $0.5 \mathrm{mg}$ T2-toxin $/ \mathrm{kg}$ diet [40].

After $4 \mathrm{mg} / \mathrm{kg}$ diet of DAS, hyperplasia of the glandular and epithelial cells in the small intestine mucosa was described in pigs [17]. Congestion and erosions of the gastric and intestinal mucosa have been described following chronic DON exposure [41]. At $4 \mathrm{mg} / \mathrm{kg}$ diet, DON may cause corrugations in the fundic region of the stomach [42], which were also observed at the jejunal level with lower doses of toxin $(2-3 \mathrm{mg} / \mathrm{kg}$ diet, Kolf-Clauw et al., unpublished results).

\subsubsection{Poultry}

T2-toxin causes dose-related necrosis and depletion of lymphocytic tissues in the digestive tract [43]. Diets containing trichothecene contamination below levels that induce a negative impact on performance could affect the small intestinal morphology. In turkey poults, T2-toxin or DAS produced shorter and thinner villi in the jejunum [44] whereas in broiler chickens, DON reduced the weight of the small intestine and induced shorter and thinner villi in the duodenum and the jejunum $[45,52]$.

Cell migration rates were reduced in the jejunum of poults fed T2-toxin but did not change in the duodenum or in poults fed DAS [44]. A slight hemorrhage was found in the initial part of the duodenum in laying hens given 1,3 or 5 $\mathrm{mg}$ NIV $/ \mathrm{kg}$ feed $(1 / 5,3 / 5$ and $2 / 4$ hens at the levels of 1,3 and $5 \mathrm{mg} \mathrm{NIV} / \mathrm{kg}$ feed, respectively [46].

\subsubsection{Humans}

Long-term exposure to Fusarium toxins has been associated with an increased incidence of esophageal cancer in China, and DON was suspected to be a risk factor [33], but the role of this toxin needs to be clarified [7]. In vitro, mitogenic effects with hyperplasia and dysplasia have been described with T2-toxin on cultured human fetal esophagus [47], but the implication of trichothecenes in human esophageal carcinogenesis needs to be further investigated.

\section{EFFECT OF TRICHOTHECENES ON INTESTINAL FUNCTIONS}

Trichothecenes have multiple effects on eukaryotic cells. At a cellular level, these toxins interfere with the active site of peptidyltransferase on ribosomes leading to the inhibition of protein synthesis [48]. Highly dividing cells, such as immune cells and intestinal epithelial cells are especially sensitive to trichothecenes and the exposure of intestinal epithelial cells to these toxins may alter their capacity to proliferate and to insure a proper barrier function.

\subsection{Effects on Mycotoxins on Nutrient Absorption}

Monogastric animals are extremely sensitive to reduced growth and weight-gain upon subchronic and chronic DON exposure. Where tissue lesions have been detected, the gastro-intestinal tract and lymphoid tissues were common targets [7]. Epithelia, particularly in the intestine, are also recognized targets for NIV and FUS-X with acute effects, such as impaired sugar and electrolyte absorption [49]. It seems likely that the morphological changes in the intestine and the reduced conversion of food are linked to an impaired absorption of nutrients [50]. As trichothecenes are potential food contaminants, their impact on nutrient absorption or transport at the intestinal level have been investigated in various species and are summarized in Table 3.

\subsubsection{Rodents}

In mice, a low dietary dose of DON $(0-10 \mathrm{mg} / \mathrm{kg}$ feed $)$ did not affect food intake but weight gain in a group receiving $10 \mathrm{mg} / \mathrm{kg}$ DON was significantly reduced. Intestinal transfer and uptake of nutrients were investigated: at the end of the feeding period, no effects were observed on the absorption of water, L-leucine, L-tryptophan, iron, or Dglucose. However, a slightly but significantly reduced transfer of glucose was observed in the group receiving 10 $\mathrm{mg} / \mathrm{kg}$ DON. Furthermore, a significant decrease (up to $50 \%$ ) of the transfer as well as tissue accumulation of 5methyltetrahydrofolic acid in the jejunal segment was observed. These findings indicate that subchronic ingestion of DON can impair intestinal transfer and uptake of nutrients [51].

\subsubsection{Poultry}

The electrophysiological properties of chicken intestinal mucosa exposed to DON were evaluated using isolated jejunum fragments in Ussing chambers [53]. Intestinal transport was determined by changes in the short-circuit current (Isc], as a measure of ion transmembrane flux, in the middle segment of the jejunum of broilers. Addition of Dglucose produced an increase in the Isc, and this was reversed by different B-trichothecenes mycotoxins including DON [50]. The Isc was decreased by the addition of Lproline on the luminal side of the isolated mucosa after DON treatment, an effect that could be attributed to a strong inhibition of the L-proline/sodium-dependent transporter by DON [53]. 
Table 3. Effect of Trichothecene Exposure on Nutrient Absorption

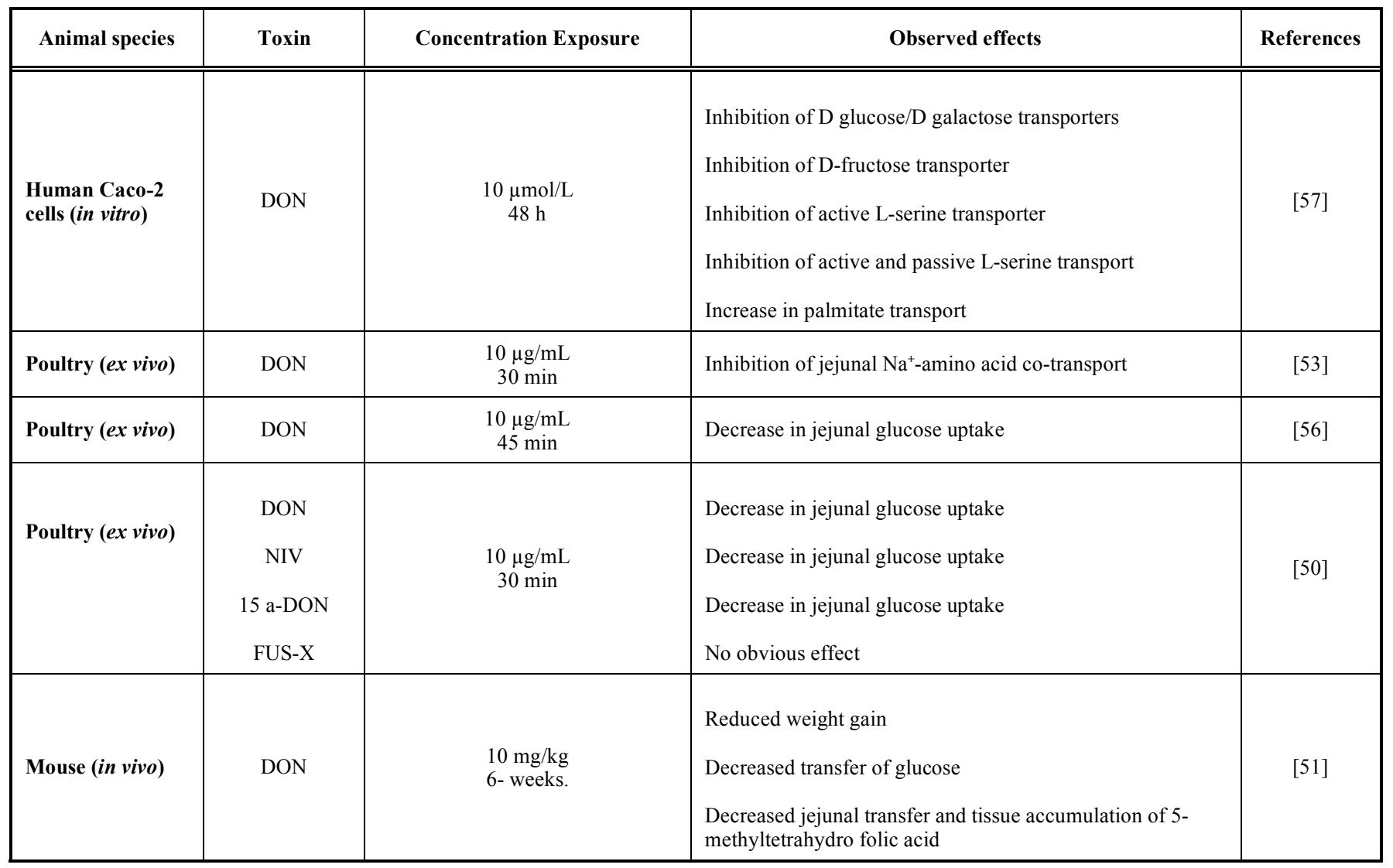

Cotransporters are specialized membrane proteins using electrochemical gradients across the membrane for transporting sugars, amino acids and ions. Recently, it has been shown that the inhibition of $\mathrm{Na}^{+}$transport and $\mathrm{Na}^{+}-\mathrm{D}$ glucose co-transport are important mechanisms of DON toxicity in the intestine of chickens [53-55]. Indeed DON treatment $(10 \mu \mathrm{g} / \mathrm{mL})$ decreased glucose uptake almost as efficiently as phlorizin, a specific inhibitor of the sodiumdependent glucose cotransporter SGLT-1 [56].

When comparing the different trichothecenes, the activity of the glucose co-transporter appears to be more sensitive to DON, NIV and 15 a-DON than to FUS-X in the jejunum of broilers [50].

\subsubsection{Humans}

In the human intestinal epithelial cell line HT-29-clone D4, exposure to $10 \mu \mathrm{mol} / \mathrm{L}$ DON affects the activities of intestinal transporters: inhibition of the D-glucose/Dgalactose sodium-dependent transporter (SGLT1), the Dfructose transporter Glucose Transporter-5 (GLUT5) and active and passive L-serine transporters was observed. The transport of palmitate was increased whereas the uptake of cholesterol was not affected by the mycotoxin. At high concentrations $(100 \mu \mathrm{mol} / \mathrm{L})$, SGLT1 activity was inhibited, whereas the activities of all the other transporters were increased [57].

\subsection{Effects of Mycotoxins on Barrier Function}

In order to maintain an effective barrier function, the intestinal epithelium rapidly entirely regenerates in approximately one week, throughout life. Mature cells derived from intestinal stem cells migrate upwards along the crypt-villus axis towards the tip of the villus, gradually differentiating as they come closer to the tip [58]. Several studies have investigated the effects of mycotoxins on intestinal epithelial cell proliferation and on intestinal morphology (Table 4). As already mentioned, trichothecenes interfere with peptidyltransferase, block protein synthesis and trigger a 'ribotoxic stress response', which involves phosphorylation of Mitogen-Activated Protein Kinases (MAPK) [59]. These signaling proteins are of particular interest because they act on epithelial cell morphology including the structure and function of the tight junctions that maintain the barrier function of the intestinal tract [60].

\subsubsection{Effects on Cell Growth}

The effect of trichothecenes on intestinal epithelial cell growth was mainly studied in the two human cell lines Caco2 and HT-29 [57, 61, 62]. When treated with a range of concentrations of DON $(84 \mathrm{nmol} / \mathrm{L}$ to $84 \mu \mathrm{mol} / \mathrm{L})$, Caco-2 cells exhibit a reduction in protein synthesis, proliferation and survival [63]. DON was also demonstrated to be 
Table 4. Effect of Trichothecene Exposure on Intestinal Barrier Function

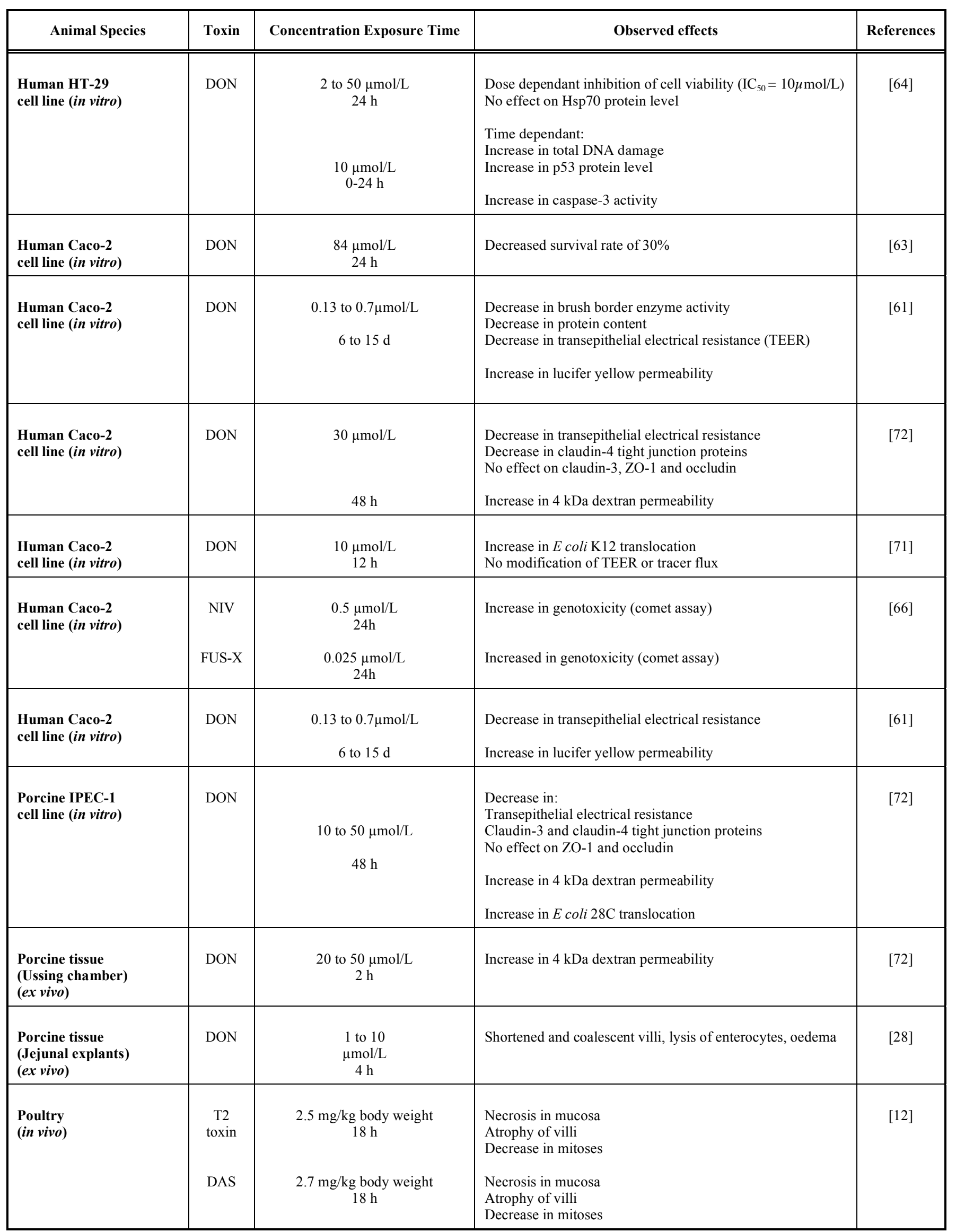




\begin{tabular}{|c|c|c|c|c|}
\hline Animal Species & Toxin & Concentration Exposure Time & Observed effects & References \\
\hline $\begin{array}{l}\text { Mouse } \\
\text { (in vivo) }\end{array}$ & $\begin{array}{l}\mathrm{T} 2 \\
\text { toxin }\end{array}$ & $\begin{array}{l}10 \mathrm{mg} / \mathrm{kg} \text { of body weight } \\
6 \mathrm{~h} \text { to } 48 \mathrm{~h}\end{array}$ & $\begin{array}{l}\text { Decrease in the mitotic index in intestinal crypt epithelia } \\
\text { Increase in the apoptotic index in crypt epithelia }\end{array}$ & [67] \\
\hline $\begin{array}{l}\text { Mouse } \\
\text { (in vivo) }\end{array}$ & DON & $\begin{array}{l}25 \mathrm{mg} / \mathrm{kg} \text { of body weight } \\
2 \mathrm{~h} \text { or } 12 \mathrm{~h}\end{array}$ & Increase susceptibility of intestinal infection by reovirus & [78] \\
\hline $\begin{array}{l}\text { Mouse } \\
\text { (in vivo) }\end{array}$ & DON & $\begin{array}{l}2 \mathrm{mg} / \mathrm{kg} \text { feed } \\
3 \mathrm{w}\end{array}$ & $\begin{array}{l}\text { Increase susceptibility to intestinal infection by Salmonella } \\
\text { enteritidis }\end{array}$ & [77] \\
\hline $\begin{array}{l}\text { Mouse } \\
\text { (in vivo) }\end{array}$ & NIV & $\begin{array}{c}20 \mathrm{mg} / \mathrm{kg} \text { (oral) } \\
2 \mathrm{~h} \text { to } 8 \mathrm{~h} \\
3.7 \mathrm{mg} / \mathrm{kg} \text { (intrapritoneal) } \\
2 \mathrm{~h}\end{array}$ & $\begin{array}{l}\text { DNA damage in jejunum and colon } \\
\text { DNA damage in colon }\end{array}$ & [82] \\
\hline
\end{tabular}

cytotoxic to the porcine intestinal epithelial cell line IPEC-1 (Pinton et al., unpublished results) and the human intestinal cell line HT-29 [64]. In this latter cell line, the cytotoxic effect of DON was not correlated with the induction of the heat shock protein, Hsp 70 or with the generation of reactive oxygen species, but was associated with a fragmentation of DNA and the activation of the apoptotic molecules p53 and caspase-3 [64].

Dividing Caco-2 cells were found to be more sensitive compared to differentiated cells [65]. The greater sensitivity of proliferating cells is probably due to the capacity of the toxin to inhibit protein synthesis and subsequently nucleic acid synthesis [66].

\subsection{Effects on Cell Differentiation}

Using scanning electron microscopy, Kasuga et al. [59] demonstrated on differentiated Caco-2 cells, that the formation of the brush border and the expression of two membrane associated hydrolases related to enterocyte differentiation were affected by DON in a dose dependent manner [61].

In mice, $\mathrm{T}-2$ toxin induced a drastic decrease in the mitotic index of the intestinal crypt epithelia 6 hours after T2 toxin inoculation. However, after 48 hours, the indices had recovered to the same value as in control mice. The apoptotic index in the crypt epithelia increased with time [67].

In broiler chicks, the ingestion of DON contaminated feed produced an alteration in the small intestinal morphology, especially in the duodenum and jejunum, where the villi were shorter and thinner [52]. In 7-day-old male broiler chickens exposed by gavage to T-2 toxin and DAS similar lesions were induced by the two toxins: atrophy of intestinal villi and fewer mitotic structure observed after 18 hours of treatment [12]. However, the lesions appeared more severe with T-2 toxin treatment. In 22-day-old male broiler chickens, T-2 toxin exposure increased the weight of the large intestine whereas no difference was observed for the small intestine [68].

\subsection{Effects on Barrier Functions}

Polarized cells form strong barriers through the development of tight junctions between them. The intercellular tight junction is the rate-limiting barrier in the paracellular pathway for permeation by ions and larger solutes [69]. The investigations concerning the effects of trichothecenes on the intestinal barrier functions are only just beginning.

\subsubsection{Effect on TEER}

Transepithelial electrical resistance (TEER) of cell monolayers can be considered as a good indicator of the degree of organization of the tight junctions within the cell monolayer and epithelial integrity [70]. Several studies have investigated the effect of trichothecenes on the TEER of intestinal epithelial cell lines (Table 4). In three different human intestinal epithelial cell lines, HT-29, Caco-2 and T84, DON was found to induce a dose-dependent decrease in the TEER [57, 61, 62, 71-73]. The same effect was observed in the porcine intestinal epithelial cell line IPEC-1 which showed a higher sensitivity to DON compared with Caco-2. Several hypotheses can explain this higher sensitivity of IPEC-1 cells [72]. Firstly, Caco-2 cells were obtained from an adenocarcinoma whereas IPEC-1 cells were derived from normal newborn piglets [74]. Secondly, even if Caco-2 cells express many morphological and biochemical characteristics of small intestine [75], they are derived from the colon. By contrast, IPEC-1 cells were obtained from jejunum and ileum. Thirdly, these two cells line are from different species (pig versus human), and among animal species, pig is the most sensitive species to DON. However it is difficult to assess the susceptibility of humans [7].

\subsubsection{Effect on Paracellular Permeability}

The observed reduction in the TEER induced by trichothecenes can be due to an alteration of the tight junction barrier properties but also to an effect on the plasma membrane such as alterations in transcellular ion transport [76]. It is thus of interest to determine the effect of these 
toxins on the paracellular permeability of a tracer such as lucifer yellow or dextran (Table 4).

Kasuga et al. [61] demonstrated a significant increase in the permeability of lucifer yellow in human Caco-2 and human T84 cells treated with DON. Similarly, we observed that DON increased the paracellular permeability of human Caco-2 cells and porcine IPEC- 1 cells to $4 \mathrm{kDa}$ dextran in a time and dose-dependent manner [72]. This effect of DON on paracellular permeability was confirmed ex vivo. Indeed, in pig explants mounted in Ussing chambers, we observed a 2-fold increase in the paracellular passage of FITC-dextran across intestinal tissue treated with $20 \mu \mathrm{mol} / \mathrm{L}$ and 50 $\mu \mathrm{mol} / \mathrm{L}$ DON, when compared to untreated ones [72].

\subsubsection{Effect on Bacterial Translocation}

Several mycotoxins, including DON, affect the integrity of tight junctions as demonstrated by the decreased TEER and the increased paracellular permeability. This could lead to the entry of luminal antigens and bacteria that are normally restricted to the gut lumen by the intestinal barrier function (Table 4). We observed that DON induces a dose dependent translocation of a pathogenic strain of Escherichia coli across the porcine IPEC-1 epithelial cell monolayers [72]. Maresca et al. [71] demonstrated that among other mycotoxins, DON allowed the transepithelial passage of apically added non-invasive commensal bacteria across human Caco-2 cell monolayers. However, in this case, no modification of paracellular permeability evaluated by the TEER measurement or tracer flux was observed. Such increase in the bacterial passage through intestinal epithelial cells after DON treatment could have major implications for human health in term of sepsis and inflammation. In mice, DON-contaminated diet accelerates Salmonella enteritidis infection [77] and transiently increases the severity of reovirus infection [78].

This effect of DON on bacterial translocation could be related to the ability of this toxin to specifically decrease the expression of claudin proteins (see below).

\subsubsection{Mechanisms Underlying the Impairment of Barrier Functions}

The mechanism underlying the trichothecene-induced impairment of the intestinal barrier function has been poorly investigated. The effect of DON on bacterial translocation could be related to the ability of this toxin to specifically decrease the expression of claudin proteins. Indeed, we have observed that, in porcine intestinal epithelial cell monolayers or in pig explants treated with DON, the increased permeability was accompanied by a specific reduction in the expression of claudins. We also observed this reduction of claudin expression in vivo in the jejunum of piglets exposed to DON -contaminated feed [72].

The MAPK signaling pathway could be involved in this phenomena. Indeed, the ribotoxic stress induced by trichothecenes leads to the activation of members of the family of Src tyrosine kinases implicated as upstream regulators of a large number of intracellular signaling pathways [79]. They likely represent critical signals that precede MAPK activation and the induction of resultant downstream responses [80]. In our study we observed that the MAPK p44/42 ERK activation, induced by DON treatment, decreased the expression of claudin in correlation with a reduction in the barrier function of the intestine evaluated by TEER and paracellular permeability [81]. We proposed a potential mechanism to explain the loss of barrier function of intestinal epithelial cells following DON exposure mediated by MAPK and claudin (Fig. 1).

\subsection{Other Effects of Trichothecenes on the Intestine}

The data on genotoxic effects of trichothecenes are scarce and this toxin is classified in group 3 (inadequate evidence) by the International Agency on Cancer Research [82]. As far as the intestine is concerned, the genotoxic potential of NIV and FUS-X, were evaluated in vitro on the human intestinal epithelial cell line Caco-2. In differentiated post-confluent cells, a short exposure (3 hours) to NIV or FUS-X did not cause any DNA damage, whereas DNA damage was observed after 24 hours or 72 hours [66]. In HT29 cells exposed to DON, Bensassi et al. [64] demonstrated that the increase in DNA damage was induced in a timedependent manner. Interestingly, in mice exposed orally and intraperitoneally to NIV $\left(50 \%\right.$ of the $\left.\mathrm{LD}_{50}\right)$ Tsuda et al. [83] observed that NIV was genotoxic in the gastrointestinal tract with the colon mucosa being preferentially damaged.

\section{TRICHOTHECENES MODULATE THE CROSS- TALK BETWEEN INTESTINAL EPITHELIAL CELLS AND IMMUNE CELLS}

As the interface between the highly antigenic luminal environment and the mucosal immune system, the intestinal epithelium plays an active role in the immune responsiveness of the intestinal mucosa with the coordinated action of both immune and non-immune cells including dendritic cells, macrophages and epithelial cells.

\subsection{Trichothecenes Modulate Cytokine Production by Intestinal Epithelial Cells}

Intestinal epithelial cells produce cytokines, crucial for the recruitment and activation of immune system cells. Several cytokines including TGF- $\alpha$, IL-1, IL-10, IL-15 and IL-18 are constitutively expressed by the intestinal epithelium and may play a role in the basal influx of immune cells into the mucosa, in epithelial cell growth and homeostasis [84]. Other cytokines such as IL-1- $\alpha$ or $\beta$, IL-6, IL-8, TNF- $\alpha$, MCP-1, CCL20 and GM-CSF are also expressed by normal epithelial cells and are markedly upregulated in response to microbial infection. Intestinal epithelial cells also play an important role in driving the development of dendritic cells [85]. They release thymic stromal lymphopoietin that inhibits IL-12 production by dendritic cells and drives the development of Th2 responses [86]. Intestinal epithelial cells also release TGF- $\beta$ and retinoic acid and are responsible for driving the development of tolerogenic dendritic cells. These cells also inhibit Th1 and Th17 cell development. In addition, thymic stromal lymphopoietin favors the release of a proliferation-inducing ligand (APRIL) and the B cell-activation factor of the TNF family (BAFF) by intestinal epithelial cell-conditioned 


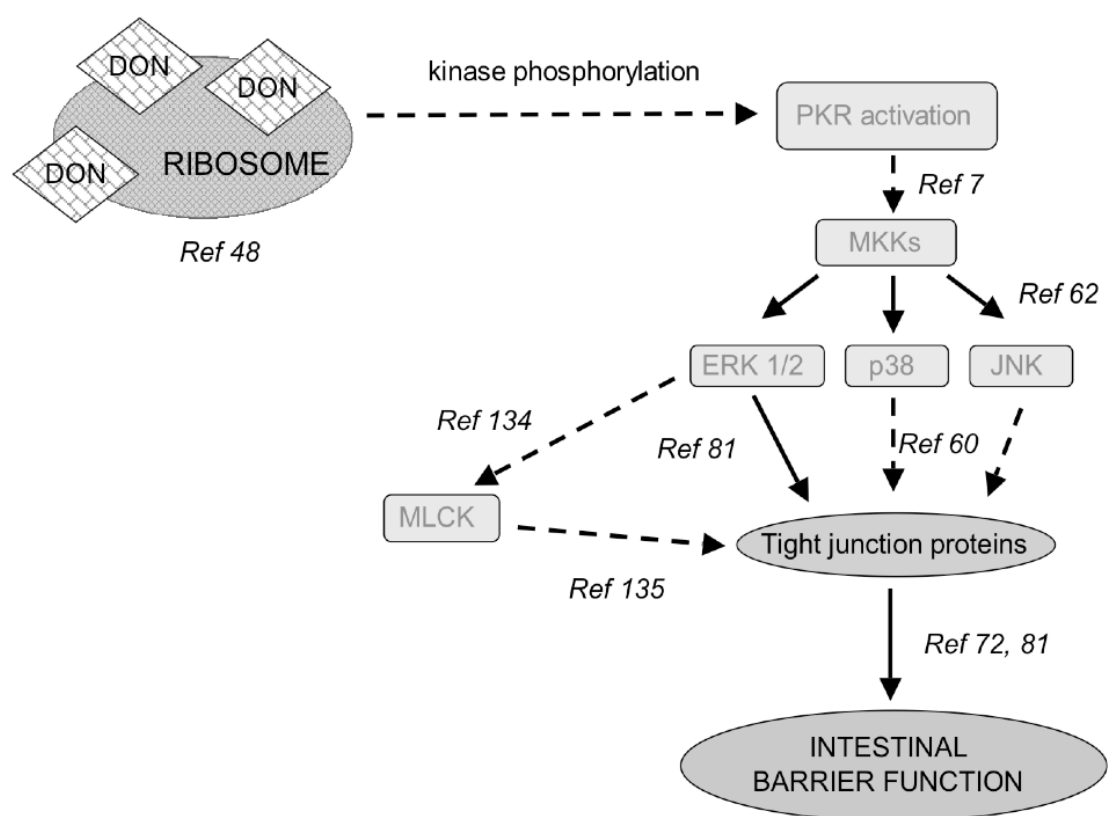

Fig. (1). Potential mechanism of action of deoxynivalenol on intestinal barrier function. DON binds to ribosomes and leads to the activation of double-stranded RNA activated protein kinase (PKR) and haemoitopoeitic cell kinase (Hck). This activation might function as signal transducer and/or scaffold to the Mitogen-activated protein kinase kinase (MKK) signaling pathway. These MKK activate the three Mitogen-activated protein kinases MAPK (ERK 1/2, p38, JNK). Phosphorylation of ERK $1 / 2$ leads to a decreased expression of tight junction proteins leading to an impaired barrier function. Alternatively, myosin light chain kinase (MLCK) activation leading to MLC phosphorylation could also participate in the decreased barrier function. Plain lines indicate demonstrated effects in intestinal epithelial cells. Dotted lines show effects demonstrated in other cell types but only hypothetically in intestinal epithelial cells.

dendritic cells and supports IgA class switching directly in the lamina propria $[87,88]$.

\subsubsection{Inflammatory Effect of Trichothecenes on Intestinal Epithelial Cells}

DON provokes intestinal inflammation in vivo [4], which results from a direct effect on the production of proinflammatory cytokines, especially IL- 8 , by intestinal epithelial cells. IL-8 is an early marker of the inflammatory process and is a potent chemo-attractant for leukocytes and T-lymphocytes underlying gut epithelial cell. IL-8 also enhances cell proliferation and controls the repair processes during injury of the intestinal mucosa or cytotoxic stress [89]. Several studies have shown that DON stimulates the secretion of IL-8 in various human intestinal epithelial cell lines $[71,73,90]$. Indeed, after exposure of Caco-2 cells to DON, a dose-dependent increase in IL-8 secretion through an NF-kB activity mechanism was observed. This effect was amplified upon pro-inflammatory stimulation (such as 25 $\mathrm{ng} / \mathrm{mL}$ IL1- $\beta, 100 \mathrm{ng} / \mathrm{mL}$ TNF or $10 \mathrm{ug} / \mathrm{mL}$ LPS), showing that DON exposure could cause or exacerbate intestinal inflammation [71]. Moreover, Maresca et al. [71] have shown that direct IL-8 secretion from differentiated Caco-2 cells in response to DON is dependent on the ribotoxicassociated activation of PKR, NF-kB and p38. By contrast, DON-induced IL-8 secretion in Int407 cells was dependent on the activation of MAPK ERK $1 / 2$ but not on the activation of $\mathrm{p} 38$. This difference is probably due to maturation status of the cells: differentiated mature Caco-2 cells versus undifferentiated Int407 cells [90].

\subsubsection{Anti-Inflammatory Effect of Trichothecenes on Intestinal Epithelial Cells}

It has been established that the detection of bacteria by intestinal epithelial cells, which induces IL-8 secretion, is exclusively mediated through the interaction of bacteria flagella with the cellular Toll-like receptor 5 [91]. An indirect pro-inflammatory effect of mycotoxins could result from an alteration of the intestinal barrier function allowing the transepithelial passage of non-invasive commensal bacteria. Indeed, high doses of DON (around $100 \mu \mathrm{mol} / \mathrm{L}$ ), compromise tight junctions and allow the transepithelial passage of apically added non-invasive commensal bacteria [71]. These authors also showed that DON at 1 and 10 $\mu \mathrm{mol} / \mathrm{L}$ potentiates the effects of basolaterally added bacteria on IL-8 secretion by human intestinal epithelial cells.

Moon et al. [92] showed that human epithelial cells are less responsive to DON-induced IL-8 production after preexposure to the endotoxin LPS. As the intestine of newborn infants becomes established with the normal microflora, their epithelium can recognize the external bacteria components. After further constitutive experience of the commensals and their endotoxins, the epithelium becomes hypo-responsive to the normal microflora and controls its associated physiological inflammation [93]. The hypo-production of IL8 in intestinal epithelial cells is due to the extended production of DON-induced PPAR- $\gamma$ after pre-exposure to endotoxin. DON was observed to elevate PPAR- $\gamma$ gene expression, which was transiently maintained. However, endotoxin pre-exposure extended the duration of DONinduced PPAR- $\gamma$ expression, thus sensitizing cells to induce an extended PPAR- $\gamma$ in response to DON treatment. PPAR- $\gamma$, 
which is constitutively expressed on the intestinal epithelial surface, may trigger the tolerance to the normal microflora and its associated inflammation [94]. For example, impaired expression of PPAR- $\gamma$ has been observed in inflammatory bowel diseases. The results demonstrated by Moon et al. [92] suggest that there is a potential risk of mucosal inflammation after DON exposure in young infants compared with endotoxin-tolerant adults.

\subsection{Trichothecenes Modulate Cytokine Production by Intestinal Immune Cells}

DON and other trichothecenes can be immunostimulatory and immunosuppressive depending on the dose, exposure frequency, and the timing of a functional immune response. Exposure to low doses of trichothecenes transcriptionally and post-transcriptionally up-regulates the expression of cytokines, chemokines and inflammatory genes with concurrent immune stimulation. High dose exposure promotes leukocyte apoptosis with concomitant immune suppression. As already mentioned, trichothecenes activate MAPK that are important transducers of downstream signaling events related to trichothecenesinduced immune stimulation and apoptosis. Indeed, p38 and ERK act as a molecular rheostat and define the response. When ERK and p38 are activated, immune gene expression is favored. When only p38 is activated, an apoptotic response ensues [95]. The effects of trichothecenes on immune cells have been mainly studied on systemic cells and to the best of our knowledge the effects of these fungal toxins on intestinal immune cells have never been investigated.

\subsubsection{Effect on Lymphocytes}

DON can directly stimulate cytokine production by immune cells. In vivo exposure to high doses of DON (5 to $25 \mathrm{mg} / \mathrm{kg}$ body weight) evokes rapid and dose-dependent TNF- $\alpha$, IL- 6 and IL1- $\beta$ mRNA upregulation in the spleen of mycotoxin treated mice $[96,97]$. By contrast exposure to a low level of the toxin (up to $0.8 \mathrm{mg} / \mathrm{kg}$ diet) does not affect the immune response of blood lymphocytes in pigs [98]. Chronic exposure of mice to NIV $(8.87 \mathrm{mg} / \mathrm{kg}$ body weight) induced a significant increase in the IL-4 level in spleen cell cultures but did not alter the levels of IL-6 and IFN- $\gamma$ [99]. In vitro exposure of the human Jurkat $\mathrm{T}$ cells, stimulated with PMA/ionomycin and exposed to increasing concentrations of DON or NIV resulted in the synthesis of mRNA encoding for IL-8 and IL-2 and IFN-g. However, higher concentrations of DON were inhibitory [100]. Similarly, DON or NIV stimulated the protein and the mRNA synthesis of IL-2, IL-4 and IL-5 in murine CD4+ T-lymphocytes stimulated with concanavalin A [101].

Besides these direct effects, DON also potentiates the effects of pro-inflammatory stimuli such as TLR-4 ligands, lipopolysaccharide (LPS) and bacteria on immune cells [102-104]. Exposure to LPS is common and can occur through infections, via gastrointestinal translocation of gut microflora due to inflammatory bowel diseases, or gut injury [105]. In mice, simultaneous exposure of subtoxic intravenous doses of LPS and dietary DON caused a sequential elevation of IL1- $\beta$ overexpression and severe apoptotic depletion of lymphoid tissue [106, 107]. However, such a mechanism needs to be demonstrated in intestinal lymphocytes during dietary exposure to LPS and trichothecenes.

\subsubsection{Effect on Macrophages}

Depending on the dose, T-2-toxin has different effects on cytokine production by murine peritoneal macrophages. At high concentrations $(2.1$ to $214 \mathrm{nmol} / \mathrm{L})$, it reduced the release of IL-12, TNF- $\alpha$, IFN- $\gamma$ and IL- 2 but enhanced them at lower concentrations [108]. DON induces IL1- $\beta$ mRNA in pig pulmonary macrophages, giving rise to possible implications of these cytokines in the DON-related symptoms such as anorexia observed in pigs in vivo [109].

Kankkunen et al. [110] showed recently that human macrophages sense trichothecene mycotoxins as a danger signal, which activates caspase-1, and further enables the secretion of IL1- $\beta$ and IL-1 8 from LPS-primed cells. This further verifies the role of the trichothecenes as DAMPs (danger-associated molecular patterns), triggering the activation of inflammasome associated caspases-1.

As already mentioned for intestinal epithelial cells, concurrent exposure of murine and human macrophages to LPS and DON greatly magnifies the synthesis of TNF- $\alpha$ and IL-6 at the mRNA and protein levels [111]. Pestka and Zhou [112] have also shown that prior TLR activation sensitizes macrophages to DON-induced proinflammatory gene expression. Similarly, co-exposure of the murine macrophage cell line, RAW 264.7, to DON and irradiated Listeria (gram positive) and Salmonella (gram negative) potentiate the proinflammatory cytokine responses [104], suggesting that activation of TLRs other than TLR4 are able to potentiate the toxicity of trichothecenes.

DON and NIV can also have suppressive effects and decrease LPS-induced NO and IFN- $\beta$ production in RAW mouse macrophage cells [113], or alter IFN- $\gamma$ mediated human blood derived macrophage activation [114].

These data may relate to the decreased host resistance to several enteric pathogens such as Salmonella enteritidis or reovirus after oral exposure to DON $[77,115]$. However the impairment of intestinal macrophage function upon ingestion of trichothecenes has never been demonstrated.

\subsubsection{Effect on Dendritic Cells}

Trichothecene-induced immunosuppression may not be exclusively due to leukocyte apoptosis. Indeed, dendritic cells, that are professional antigen-presenting cells responsible for initiating and suppressing immune responses [115], are likely mediators for the suppressive effects of trichothecenes on the immune system.

The effect of trichothecenes (DON, NIV and T2-toxin) on dendritic cells has been described in four recent publications [116-119]. These studies indicate that in vitro treatment of murine dendritic cells and human or porcine monocyte-derived dendritic cells with these toxins interfered with their maturation as evidence by phenotypic marker antigen uptake, endocytosis and cytokine secretion. Chronic dietary exposure of pigs to DON (3.5 to $5.5 \mathrm{mg} / \mathrm{kg}$ diet) resulted in the generation of dendritic cells that failed to mature in response to LPS/TNF- $\alpha$, but acquired a more 
mature phenotype in response to DON-treatment in vitro [117]. These effects may be mediated by the activation of MAPK, resulting in abnormal activation of transcription factors and, as a consequence, disruption of transcriptional and translational functions. Trichothecenes may also interfere with the maturation and functions of intestinal dendritic cells but this aspect of trichothecenes has never been investigated.

\subsection{Trichothecenes may Interfere in the Cross-Talk Between Epithelial Cells and Intestinal Immune Cells}

As described previously, epithelial cells act as initiators, mediators, and regulators in innate and adaptive immune responses, as well as in the transition from innate immunity to adaptive immunity. Dendritic cells collaborate as sentinels against foreign particulate antigens by building a transepithelial interacting cellular network. During inflammatory and immune responses, epithelial cells express pattern-recognition receptors to trigger a host defense response and interact with dendritic cells to regulate antigen sensitization, and release cytokines to recruit effector cells [120]. However, macrophages and $\mathrm{T}$ cells are also able to modulate dendritic cell functions [121].

The effects of trichothecenes on the different cell types involved in gut homeostasis can explain various pathologies associated with the ingestion of mycotoxin contaminated food.

Firstly, DON can potentiate the effect of IL1- $\beta$ on IL-8 secretion and increase the transepithelial passage of commensal bacteria $[71,72]$. IL-8 has been implicated in many chronic diseases ranging from inflammatory bowel disease [122, 123] to rheumatoid arthritis [124]. Then, in addition to potentially exacerbating established intestinal inflammation, this mycotoxin may thus participate in the induction of sepsis and intestinal inflammation in vivo [71]. Indeed, inflammatory bowel diseases, such as Crohn's disease, are generally associated with the presence of adherent-invasive bacteria [125]. A hypothesis would be that at least in some cases, ingestion of food contaminated with mycotoxins could be involved in inducing inflammatory bowel diseases [62, 71, 72].

The induction of proinflammatory cytokines such as IL-6 by macrophages plays a pivotal role as they are directly linked to the differentiation of B-cells and to the stimulation of IgA secretion [126]. Prolonged feeding of DON causes a dramatic elevation in total serum IgA in mice. Moreover, dietary exposure to DON or NIV selectively up-regulates membrane IgA bearing cells in mouse Peyer's patches [126]. IL-6 is critical to mucosal IgA immunity based both on its differentiative effects on IgA-committed B cells and its production in the gut by macrophages and $\mathrm{T}$ cells [127]. DON up-regulates IL-6 expression in vivo and in vitro and that drives the differentiation of IgA-committed B cells to IgA secretion [128-130], mimicking the early stage of human IgA nephropathy. It will be interesting to study the implication of trichothecenes on the release of soluble molecules such as thymic stromal lymphopoietin, retinoic acid and TNF- $\beta$ by intestinal epithelial cells. Indeed, thymic stromal lymphopoietin is shown to favor the release of BAFF and APRIL by conditioned dendritic cells and induce
IgA switching directly in the lamina propria. The disruption of gut homeostasis induced by trichothecenes could explain the modification of mucosal IgA responses as well as the diverse immune-mediated pathology observed in response to these fungal toxins.

\section{CONCLUSION}

The intestinal mucosa is the first biological barrier encountered by natural toxins and consequently it could be exposed to high amounts of dietary toxins. An increasing number of studies demonstrate that intestinal epithelial cells are targets for food contaminants including mycotoxins [131-133]. Ingestion of trichothecenes induces intestinal pathologies in humans and animals, including necrosis of the intestinal epithelium. These mycotoxins also disturb the barrier function potentially leading to increased translocation of pathogens or contaminants. Trichothecenes modulate the immune responsiveness of the intestinal mucosa and may interact in the cross-talk between epithelial cells and intestinal immune cells. The exposure to these mycotoxins, following ingestion of contaminated food and feed, can increase susceptibility to enteric infectious diseases but they can also contribute to the predisposition to inflammatory diseases. The intestinal toxicity of trichothecenes raises however, several questions: why are intestinal lesions induced whatever the route of administration? What is the physiological basis for the differential sensitivity among animal species? What is the mechanism underlying the intestinal toxicity of these toxins? What are the effects of trichothecenes on the commensal bacteria and the consequences on the development of tolerance? How can the data obtained using in vivo animal models, ex vivo models and in vitro models relate to the sparse epidemiological date obtained on humans? To what extent does the modulation of cytokine synthesis by trichothecenes affect the intestinal immune response and what are the consequences for the development of inflammatory intestinal diseases?

\section{ACKNOWLEDGMENTS}

This work was supported by EC projects KBBE-2007222690-2, MYCORED, KBBE-2008-227549, INTERPLAY and by the French ANR-CESA project, DON \& Co. The authors are solely responsible for the work described in this article, and their opinions are not necessarily those of the European Union. We thank Dr John Woodley, Paul Sabatier University, Toulouse for language editing.

\section{REFERENCES}

[1] Groschwitz KR, Hogan SP. Intestinal barrier function: molecular regulation and disease pathogenesis. J Allergy Clin Immunol 2009; 124: 3-20.

[2] Pitman RS, Blumberg RS. First line of defense: the role of the intestinal epithelium as an active component of the mucosal immune system. J Gastroenterol 2000; 35: 805-14.

[3] Turner JR. Intestinal mucosal barrier function in health and disease. Nat Rev Immunol 2009; 9: 799-809.

[4] Bouhet S, Oswald IP. The effects of mycotoxins, fungal food contaminants, on the intestinal epithelial cell-derived innate immune response. Vet Immunol Immunopathol 2005; 108: 199209. 
[5] Oswald IP, Marin DE, Bouhet S, Pinton P, Taranu I, Accensi F. Immunotoxicological risk of mycotoxins for domestic animals. Food Addit Contam 2005; 22: 354-60.

[6] Chu FS. Mycotoxins-Occurrence and toxic effects. In: Encyclopedia of Food and Nutrition. Food contaminants, Second edition, Academic Press, NY. 1998; 858-869.

[7] Pestka JJ, Smolinski AT. Deoxynivalenol: toxicology and potential effects on humans. J Toxicol Environ Health B Crit Rev 2005; 8: 39-69.

[8] Larsen JC, Hunt J, Perrin I, Ruckenbauer P. Workshop on trichothecenes with a focus on DON: summary report. Toxicol Lett 2004; 153: 1-22

[9] Sugita-Konishi Y, Park BJ, Kobayashi-Hattori K, et al. Effect of cooking process on the deoxynivalenol content and its subsequent cytotoxicity in wheat products. Biosci Biotechnol Biochem 2006; 70: 1764-8.

[10] Awad, W. A., Razzazi-Fazeli, E., Bohm, J. and Zentek, J. Influence of deoxynivalenol on the D-glucose transport across the isolated epithelium of different intestinal segments of laying hens. J Anim Physiol Anim Nutr 2007; 91: 175-80.

[11] Zielonka L, Wisniewska M, Gajecka M, Obremski K, Gajecki M. Influence of low doses of deoxynivalenol on histopathology of selected organs of pigs. Pol J Vet Sci. 2009;12: 89-95.

[12] Hoerr FJ, Carlton WW, Yagen B. Mycotoxicosis caused by a single dose of T-2 toxin or DAS in broiler chickens. Vet Pathol 1981; 18: 652-64.

[13] Huff WE, Doerr JA, Hamilton PB, Vesonder RF. Acute toxicity of vomitoxin (Deoxynivalenol) in broiler chickens. Poult Sci 1981; 60: $1412-4$.

[14] Lutsky I, Mor N, Yagen B, Joffe AZ. The role of T-2 toxin in experimental alimentary toxic aleukia: a toxicity study in cats. Toxicol Appl Pharmacol 1978; 43: 111-24.

[15] Richardson KE, Hamilton PB. Comparative toxicity of scirpentriol and its acetylated derivatives. Poult Sci 1990; 69: 397-402.

[16] Weaver GA, Kurtz HJ, Bates FY, et al. Acute and chronic toxicity of T-2 mycotoxin in swine. Vet Rec 1978; 103: 531-535.

[17] Weaver GA, Kurtz HJ, Bates FY, Mirocha CJ, Behrens JC, Hagler WM. Diacetoxyscirpenol toxicity in pigs. Res Vet Sci 1981; 31: 131-5.

[18] Weaver GA, Kurtz HJ, Mirocha CJ, Bates FY, Behrens JC. Acute toxicity of the mycotoxin DAS in swine. Can Vet J 1978; 19: 26771.

[19] Conner MW, de Camargo J, Punyarit P, Riengropitak S, Rogers AE, Newberne PM. Toxicity of anguidine in mice. Fundam Appl Toxicol 1986; 7: 153-64.

[20] Creasia DA, Thurman JD, Jones LJ, et al. Acute inhalation toxicity of T-2 mycotoxin in mice. Fundam Appl Toxicol 1987; 8: 230-5

[21] Creasia DA, Thurman JD, Wannemacher RW, Jr., Bunner DL. Acute inhalation toxicity of T-2 mycotoxin in the rat and guinea pig. Fundam Appl Toxicol 1990; 14:54-9.

[22] Forsell JH, Jensen R, Tai JH, Witt M, Lin WS, Pestka JJ. Comparison of acute toxicities of deoxynivalenol (vomitoxin) and 15-acetyldeoxynivalenol in the B6C3F1 mouse. Food Chem Toxicol 1987; 25 : 155-62.

[23] Glavits R, Vanyi A, Fekete S, Tamas J. Acute toxicological experiment of T-2 toxin in rabbits. Acta Vet Hung 1989; 37: 75-9.

[24] Matsuoka Y, Kubota K, Ueno Y. General pharmacological studies of FUS-X, a trichothecene mycotoxin from Fusarium species. Toxicol Appl Pharmacol 1979; 50: 87-94.

[25] Li J, Shimizu T. Course of apoptotic changes in the rat gastric mucosa caused by oral administration of FUS-X. J Vet Med Sci 1997; 59: 191-9.

[26] Haschek W, Beasley V. In: Ramesh Gupta Trichothecenes mycotoxins Handbook of Toxicology of Chemical Warfare Agents. Murray State University, Breathitt Veterinary Center, Hopkinsville, KY, USA. 2009; 353-69.

[27] Coppock RW, Swanson SP, Gelberg HB, et al. Preliminary study of the pharmacokinetics and toxicopathy of deoxynivalenol (vomitoxin) in swine. Am J Vet Res 1985; 46: 169-74.

[28] Kolf-Clauw M, Castellote J, Joly B, et al. Development of a pig jejunal explant culture for studying the gastrointestinal toxicity of the mycotoxin deoxynivalenol: histopathological analysis. Toxicol In Vitro 2009; 23: 1580-4

[29] Hedman R, Pettersson H, Engstrom B, Elwinger K, Fossum O. Effects of feeding nivalenol-contaminated diets to male broiler chickens. Poult Sci 1995; 74: 620-5.
[30] Forgacs J, Carll WT. Alimentary toxic aleukia (ATA) in man Mycotoxicoses. Adv Vet Sci 1962; 7: 347-58

[31] Lafont P, Lafarge-Frayssinet C, Lafont J, Bertin G, Frayssinet F. Toxic metabolites from Fusarium causing alimentary toxic aleukia. Ann Microbiol 1977; 128: 215-20.

[32] Lutsky I, Mor N. Experimental alimentary toxic aleukia in cats. Lab Anim Sci 1981; 31: 43-7.

[33] Luo Y, Yoshizawa T, Katayama T. Comparative study on the natural occurrence of Fusarium mycotoxins (trichothecenes and zearalenone) in corn and wheat from high- and low-risk areas for human esophageal cancer in China. Appl Environ Microbiol 1990; 56: 3723-6.

[34] Bhat RV, Beedu SR, Ramakrishna Y, Munshi KL. Outbreak of trichothecene mycotoxicosis associated with consumption of mould-damaged wheat production in Kashmir Valley, India. Lancet 1989; 1: 35-7.

[35] Fekete S, Tamas J, Vanyi A, Glavits R, Bata A. Effect of T-2 toxin on feed intake, digestion and pathology of rabbits. Lab Anim Sci 1989; 39: 603-6.

[36] Hayes MA, Bellamy JE, Schiefer HB. Subacute toxicity of dietary T-2 toxin in mice: morphological and hematological effects. Can J Comp Med 1980; 44: 203-18.

[37] Ohtsubo K, Ryu JC, Nakamura K, et al. Chronic toxicity of nivalenol in female mice: a 2-year feeding study with Fusarium nivale Fn 2B-moulded rice. Food Chem Toxicol 1989; 27: 591-8.

[38] Schiefer HB, Rousseaux CG, Hancock DS, Blakley BR. Effects of low-level long-term oral exposure to T-2 toxin in CD-1 mice. Food Chem Toxicol 1987; 25: 593-601.

[39] Harvey RB, Kubena LF, Huff WE, Corrier DE, Rottinghaus GE, Phillips TD. Effects of treatment of growing swine with aflatoxin and T-2 toxin. Am J Vet Res 1990; 51: 1688-93.

[40] Rafai P, Bata A, Vanyi A, et al. Effect of various levels of T-2 toxin on the clinical status, performance and metabolism of growing pigs. Vet Rec. 1995; 136: 485-9.

[41] Cote LM, Reynolds JD, Vesonder RF, et al. Survey of vomitoxincontaminated feed grains in midwestern United States, and associated health problems in swine. J Am Vet Med Assoc. 1984; 184: 189-92.

[42] D'Mello JPF. Antinutritional factors and mycotoxins. In: D'Mello JFP Ed, Farm animal metabolism and nutrition. Wallingford, UK, CAB International. 2000; 383-403.

[43] Hoerr FJ, Carlton WW, Yagen B, Joffe AZ. Mycotoxicosis produced in broiler chickens by multiple doses of either T-2 toxin or DAS. Avian Pathol 1982; 11:369-83.

[44] Sklan D, Shelly M, Makovsky B, Geyra A, Klipper E, Friedman A The effect of chronic feeding of DAS and T-2 toxin on performance, health, small intestinal physiology and antibody production in turkey poults. Br Poult Sci 2003; 44: 46-52.

[45] Awad WA, Bohm J, Razzazi-Fazeli E, Zentek J. Effects of feeding deoxynivalenol contaminated wheat on growth performance, organ weights and histological parameters of the intestine of broiler chickens. J Anim Physiol Anim Nutr (Berl) 2006; 90: 32-7.

[46] Garaleviciene D, Pettersson H, Elwinger K. Effects on health and blood plasma parameters of laying hens by pure nivalenol in the diet. J Anim Physiol Anim Nutr (Berl) 2002; 86: 389-98.

[47] Hsia CC, Tzian BL, Harris CC. Proliferative and cytotoxic effects of Fusarium T2 toxin on cultured human fetal esophagus. Carcinogenesis 1983; 4: 1101-7.

[48] Rocha O, Ansari K, Doohan FM. Effects of trichothecene mycotoxins on eukaryotic cells: a review. Food Addit Contam 2005; $22: 369-78$.

[49] Kumagai S, Shimizu T. Effects of FUS-X and T-2 toxin on intestinal absorption of monosaccharide in rats. Arch Toxicol. 1988; 61: 489-95.

[50] Awad WA, Razzazi-Fazeli E, Bohm J, Zentek J. Effects of Btrichothecenes on luminal glucose transport across the isolated jejunal epithelium of broiler chickens. J Anim Physiol Anim Nutr 2008; 92: 225-30.

[51] Hunder G, Schumann K, Strugala G, Gropp J, Fichtl B, Forth W. Influence of subchronic exposure to low dietary deoxynivalenol, a trichothecene mycotoxin, on intestinal absorption of nutrients in mice. Food Chem Toxicol 1991; 29: 809-14.

[52] Awad WA, Bohm J, Razzazi-Fazeli E, Ghareeb K, Zentek J. Effect of addition of a probiotic microorganism to broiler diets contaminated with deoxynivalenol on performance and histological 
alterations of intestinal villi of broiler chickens. Poult Sci 2006; 85: 974-9.

[53] Awad WA, Rehman H, Bohm J, Razzazi-Fazeli E, Zentek J. Effects of luminal deoxynivalenol and L-proline on electrophysiological parameters in the jejunums of laying hens. Poult Sci 2005; 84: 928-32.

[54] Awad WA, Bohm J, Razzazi-Fazeli E, Hulan HW, Zentek J. Effects of deoxynivalenol on general performance and electrophysiological properties of intestinal mucosa of broiler chickens. Poult Sci 2004; 83: 1964-72.

[55] Awad WA, Bohm J, Razzazi-Fazeli E, Zentek J. In vitro effects of deoxynivalenol on electrical properties of intestinal mucosa of laying hens. Poult Sci 2005; 84: 921-7.

[56] Awad WA, Aschenbach JR, Setyabudi FM, Razzazi-Fazeli E, Bohm J, Zentek J. In vitro effects of deoxynivalenol on small intestinal D-glucose uptake and absorption of deoxynivalenol across the isolated jejunal epithelium of laying hens. Poult Sci 2007; 86: 15-20.

[57] Maresca M, Mahfoud R, Garmy N, Fantini J. The mycotoxin deoxynivalenol affects nutrient absorption in human intestinal epithelial cells. J Nutr 2002; 132: 2723-31.

[58] Booth C, Potten CS. Gut instincts: thoughts on intestinal epithelial stem cells. J Clin Invest 2000; 105: 1493-9.

[59] Moon Y, Pestka JJ. Vomitoxin-induced cyclooxygenase-2 gene expression in macrophages mediated by activation of ERK and p38 but not JNK mitogen-activated protein kinases. Toxicol Sci 2002; 69: $373-82$.

[60] Oshima T, Miwa H, Joh T. Aspirin induces gastric epithelial barrier dysfunction by activating p38 MAPK via claudin-7. Am J Physiol Cell Physiol 2008; 295: C800-6.

[61] Kasuga F, Hara-Kudo Y, Saito N, Kumagai S, Sugita-Konishi Y. In vitro effect of deoxynivalenol on the differentiation of human colonic cell lines Caco-2 and T84. Mycopathologia 1998; 142: 1617 .

[62] Sergent T, Parys M, Garsou S, Pussemier L, Schneider YJ, Larondelle Y. Deoxynivalenol transport across human intestinal Caco-2 cells and its effects on cellular metabolism at realistic intestinal concentrations. Toxicol Lett 2006; 164: 167-76.

[63] Instanes C, Hetland G. Deoxynivalenol (DON) is toxic to human colonic, lung and monocytic cell lines, but does not increase the IgE response in a mouse model for allergy. Toxicology 2004; 204 : 13-21.

[64] Bensassi F, El Golli-Bennour E, Abid-Essefi S, Bouaziz C, Hajlaoui MR, Bacha H. Pathway of deoxynivalenol-induced apoptosis in human colon carcinoma cells. Toxicology 2009; 264 : 104-9.

[65] Bony S, Carcelen M, Olivier L, Devaux A. Genotoxicity assessment of deoxynivalenol in the Caco-2 cell line model using the Comet assay. Toxicol Lett 2006; 166: 67-76.

[66] Bony S, Olivier-Loiseau L, Carcelen M, Devaux A. Genotoxic potential associated with low levels of the Fusarium mycotoxins nivalenol and fusarenon $\mathrm{X}$ in a human intestinal cell line. Toxicol In Vitro 2007; 21: 457-65.

[67] Li G, Shinozuka J, Uetsuka K, Nakayama H, Doi K. T-2 toxininduced apoptosis in intestinal crypt epithelial cells of mice. Exp Toxicol Pathol. 1997; 49: 447-50.

[68] Rezar V, Frankic T, Narat M, Levart A, Salobir J. Dose-dependent effects of T-2 toxin on performance, lipid peroxidation, and genotoxicity in broiler chickens. Poult Sci 2007; 86: 1155-60.

[69] Madara JL. Regulation of the movement of solutes across tight junctions. Annu Rev Physiol 1998; 60: 143-59.

[70] Harhaj NS, Antonetti DA. Regulation of tight junctions and loss of barrier function in pathophysiology. Int J Biochem Cell Biol 2004; 36: 1206-37.

[71] Maresca M, Yahi N, Younes-Sakr L, Boyron M, Caporiccio B, Fantini J. Both direct and indirect effects account for the proinflammatory activity of enteropathogenic mycotoxins on the human intestinal epithelium: Stimulation of interleukin- 8 secretion, potentiation of interleukin-1beta effect and increase in the transepithelial passage of commensal bacteria. Toxicol Appl Pharmacol 2008; 228: 84-92.

[72] Pinton P, Nougayrede JP, Del Rio JC, et al. The food contaminant deoxynivalenol, decreases intestinal barrier permeability and reduces claudin expression. Toxicol Appl Pharmacol 2009; 237: $41-8$.
[73] Van De Walle J, Romier B, Larondelle Y, Schneider YJ. Influence of deoxynivalenol on NF-kappaB activation and IL-8 secretion in human intestinal Caco-2 cells. Toxicol Lett 2008; 177: 205-14.

[74] Gonzalez-Vallina R, Wang H, Zhan R, et al. Lipoprotein and apolipoprotein secretion by a newborn piglet intestinal cell line (IPEC-1). Am J Physiol 1996; 271: G249-59.

[75] Pinto M, Robine-Leon S, Appay M. Enterocyte-like differentiation and polarization of the human colon carcinoma cell line Caco-2 in culture. Bio Cell 1983; 47: 323-30.

[76] Barrett KE. Positive and negative regulation of chloride secretion in T84 cells. Am J Physiol 1993; 265: C859-68.

[77] Hara-Kudo Y, Sugita-Konoshi Y, Kasuga F, Kumagai S. Effects of deoxynivalenol on Salmonella enteritidis infection. Mycotoxins 1996; 42: 51-5.

[78] Li M, Cuff CF, Pestka JJ. Modulation of Murine Host Response to Enteric Reovirus Infection by the Trichothecene Deoxynivalenol. Toxicol Sci 2005; 87: 134-45.

[79] Lowell CA. Src-family kinases: rheostats of immune cell signaling. Mol Immunol 2004; 41: 631-43.

[80] Zhou HR, Jia Q, Pestka JJ. Ribotoxic stress response to the trichothecene deoxynivalenol in the macrophage involves the SRC family kinase Hck. Toxicol Sci 2005; 85: 916-26.

[81] Pinton P, Braicu C, Nougayrede JP, Laffitte J, Taranu I, Oswald IP. Deoxynivalenol impairs porcine intestinal barrier function and decreases the protein expression of claudin-4 through a Mitogen Activated Protein kinase dependant mechanism. J. Nutr. 2010; 140:1956-62.

[82] IARC (International Agency for Research on Cancer). Monographs on the evaluation of carcinogenic risks to humans; Vol. 56: Some naturally occurring substances, food items and constituents, heterocyclic aromatic amines and mycotoxins. International Agency for Research on Cancer, World Health Organization, Lyon, France. 1993; 397-444

[83] Tsuda S, Kosaka Y, Murakami M, et al. Detection of nivalenol genotoxicity in cultured cells and multiple mouse organs by the alkaline single-cell gel electrophoresis assay. Mutat Res 1998; 415: 191-200.

[84] Stadnyk AW. Intestinal epithelial cells as a source of inflammatory cytokines and chemokines. Can J Gastroenterol 2002; 16: 241-6.

[85] Iliev ID, Matteoli G, Rescigno M. The yin and yang of intestinal epithelial cells in controlling dendritic cell function. J Exp Med 2007; 204: 2253-7.

[86] Rimoldi M, Chieppa M, Larghi P, Vulcano M, Allavena P, Rescigno M. Monocyte-derived dendritic cells activated by bacteria or by bacteria-stimulated epithelial cells are functionally different. Blood 2005; 106: 2818-26.

[87] Chen F, Ma Y, Xue C, et al. The combination of deoxynivalenol and zearalenone at permitted feed concentrations causes serious physiological effects in young pigs. J Vet Sci 2008; 9: 39-44.

[88] Rescigno M, Di Sabatino A. Dendritic cells in intestinal homeostasis and disease. J Clin Invest 2009; 119: 2441-50.

[89] Maheshwari A, Lacson A, Lu W, et al. Interleukin-8/CXCL8 forms an autocrine loop in fetal intestinal mucosa. Pediatr Res 2004; 56: 240-9.

[90] Moon Y, Yang H, Lee SH. Modulation of early growth response gene 1 and interleukin- 8 expression by ribotoxin deoxynivalenol (vomitoxin) via ERK1/2 in human epithelial intestine 407 cells. Biochem Biophys Res Commun 2007; 362: 256-62.

[91] Bambou JC, Giraud A, Menard S, et al. In vitro and ex vivo activation of the TLR5 signaling pathway in intestinal epithelial cells by a commensal Escherichia coli strain. J Biol Chem 2004; 279: 42984-92.

[92] Moon Y, Yang H, Park SH. Hypo-responsiveness of interleukin-8 production in human embryonic epithelial intestine 407 cells independent of NF-kappaB pathway: new lessons from endotoxin and ribotoxic deoxynivalenol. Toxicol Appl Pharmacol 2008; 231: 94-102.

[93] Borka K, Kaliszky P, Szabo E, et al. Claudin expression in pancreatic endocrine tumors as compared with ductal adenocarcinomas. Virchows Arch 2007; 450: 549-57.

[94] Eun CS, Han DS, Lee SH, et al. Attenuation of colonic inflammation by PPARgamma in intestinal epithelial cells: effect on Toll-like receptor pathway. Dig Dis Sci 2006; 51: 693-7.

[95] Pestka JJ, Zhou HR, Moon Y, Chung YJ. Cellular and molecular mechanisms for immune modulation by deoxynivalenol and other 
trichothecenes: unraveling a paradox. Toxicol Lett 2004; 153: 6173.

[96] Azcona-Olivera JI, Ouyang Y, Murtha J, Chu FS, Pestka JJ. Induction of cytokine mRNAs in mice after oral exposure to the trichothecene vomitoxin (deoxynivalenol): relationship to toxin distribution and protein synthesis inhibition. Toxicol Appl Pharmacol 1995; 133: 109-20.

[97] Zhou HR, Yan D, Pestka JJ. Differential cytokine mRNA expression in mice after oral exposure to the trichothecene vomitoxin (deoxynivalenol): dose response and time course. Toxicol Appl Pharmacol 1997; 144: 294-305.

[98] Accensi F, Pinton P, Callu P, et al. Ingestion of low doses of deoxynivalenol does not affect hematological, biochemical, or immune responses of piglets. J Anim Sci 2006; 84: 1935-42.

[99] Gouze ME, Laffitte J, Pinton P, et al. Effect of subacute oral doses of nivalenol on immune and metabolic defence systems in mice. Vet Res 2007; 38: 635-46.

[100] Severino L, Luongo D, Bergamo P, Lucisano A, Rossi M. Mycotoxins nivalenol and deoxynivalenol differentially modulate cytokine mRNA expression in Jurkat T cells. Cytokine 2006; 36: 75-82.

[101] Ouyang YL, Azcona-Olivera JI, Pestka JJ. Effects of trichothecene structure on cytokine secretion and gene expression in murine CD4+ T-cells. Toxicology 1995; 104:187-202.

[102] Islam Z, Gray JS, Pestka JJ. p38 Mitogen-activated protein kinase mediates IL-8 induction by the ribotoxin deoxynivalenol in human monocytes. Toxicol Appl Pharmacol 2006; 213: 235-44.

[103] Zhou HR, Harkema JR, Yan D, Pestka JJ. Amplified proinflammatory cytokine expression and toxicity in mice coexposed to lipopolysaccharide and the trichothecene vomitoxin (deoxynivalenol). J Toxicol Environ Health A 1999; 57: 115-36.

[104] Mbandi E, Pestka JJ. Deoxynivalenol and satratoxin G potentiate proinflammatory cytokine and macrophage inhibitory protein 2 induction by Listeria and Salmonella in the macrophage. J Food Prot 2006; 69: 1334-9.

[105] Van Leeuwen PA, Boermeester MA, Houdijk AP, et al. Clinical significance of translocation. Gut 1994; 35: S28-34.

[106] Islam Z, Moon YS, Zhou HR, King LE, Fraker PJ, Pestka JJ. Endotoxin potentiation of trichothecene-induced lymphocyte apoptosis is mediated by up-regulation of glucocorticoids. Toxicol Appl Pharmacol 2002; 180: 43-55.

[107] Islam Z, Pestka JJ. Role of IL-1(beta) in endotoxin potentiation of deoxynivalenol-induced corticosterone response and leukocyte apoptosis in mice. Toxicol Sci 2003; 74: 93-102.

[108] Ahmadi K, Riazipour M. Effects of T-2 toxin on cytokine production by mice peritoneal macrophages and lymph node $\mathrm{T}$ cells. Iran J Immunol 2008; 5: 177-80.

[109] Doll S, Schrickx JA, Danicke S, Fink-Gremmels J. Deoxynivalenol-induced cytotoxicity, cytokines and related genes in unstimulated or lipopolysaccharide stimulated primary porcine macrophages. Toxicol Lett 2009; 184: 97-106.

[110] Kankkunen P, Rintahaka J, Aalto A, et al. Trichothecene mycotoxins activate inflammatory response in human macrophages. J Immunol 2009; 182: 6418-25.

[111] Chung YJ, Zhou HR, Pestka JJ. Transcriptional and posttranscriptional roles for $\mathrm{p} 38$ mitogen-activated protein kinase in upregulation of TNF-alpha expression by deoxynivalenol (vomitoxin). Toxicol Appl Pharmacol 2003; 193: 188-201.

[112] Pestka J, Zhou HR. Toll-like receptor priming sensitizes macrophages to proinflammatory cytokine gene induction by deoxynivalenol and other toxicants. Toxicol Sci 2006; 92: 445-55.

[113] Sugiyama KI, Muroi M, Tanamoto KI, Nishijima M, SugitaKonishi Y. Deoxynivalenol and nivalenol inhibit lipopolysaccharide-induced nitric oxide production by mouse macrophage cells. Toxicol Lett 2009; 192: 150-154

[114] Wache YJ, Hbabi-Haddioui L, Guzylack-Piriou L, Belkhelfa H, Roques C, Oswald IP. The mycotoxin Deoxynivalenol inhibits the cell surface expression of activation markers in human macrophages. Toxicology 2009; 262: 239-44.

[115] Li M, Cuff CF, Pestka J. Modulation of murine host response to enteric reovirus infection by the trichothecene deoxynivalenol. Toxicol Sci 2005; 87: 134-45.

[116] Fleeton M, Contractor N, Leon F, et al. Involvement of dendritic cell subsets in the induction of oral tolerance and immunity. Ann N Y Acad Sci 2004; 1029: 60-5.
[117] Bimczok D, Doll S, Rau H, et al. The Fusarium toxin deoxynivalenol disrupts phenotype and function of monocytederived dendritic cells in vivo and in vitro. Immunobiology 2007; 212: 655-66.

[118] Luongo D, Severino L, Bergamo P, D'Arienzo R, Rossi M. Trichothecenes NIV and DON modulate the maturation of murine dendritic cells. Toxicon 2010; 55: 73-80.

[119] Hymery N, Sibiril Y, Parent-Massin D. In vitro effects of trichothecenes on human dendritic cells. Toxicol In Vitro 2006; 20: 899-909.

[120] Oswald IP. Role of intestinal epithelial cells in the innate immune defence of the pig intestine. Vet Res 2006; 37: 359-68.

[121] Denning TL, Wang YC, Patel SR, Williams IR, Pulendran B. Lamina propria macrophages and dendritic cells differentially induce regulatory and interleukin 17-producing $\mathrm{T}$ cell responses. Nat Immunol 2007; 8: 1086-94.

[122] Alzoghaibi MA, Walsh SW, Willey A, Fowler AA, 3rd, Graham MF. Linoleic acid, but not oleic acid, upregulates the production of interleukin- 8 by human intestinal smooth muscle cells isolated from patients with Crohn's disease. Clin Nutr 2003; 22: 529-35.

[123] Banks C, Bateman A, Payne R, Johnson P, Sheron N. Chemokine expression in IBD. Mucosal chemokine expression is unselectively increased in both ulcerative colitis and Crohn's disease. J Pathol 2003; 199: 28-35.

[124] Georganas C, Liu H, Perlman H, Hoffmann A, Thimmapaya B, Pope RM. Regulation of IL-6 and IL-8 expression in rheumatoid arthritis synovial fibroblasts: the dominant role for NF-kappa B but not C/EBP beta or c-Jun. J Immunol 2000; 165: 7199-206.

[125] Martin HM, Campbell BJ, Hart CA, et al. Enhanced Escherichia coli adherence and invasion in Crohn's disease and colon cancer. Gastroenterology 2004; 127: 80-93.

[126] Pestka JJ. Deoxynivalenol-induced IgA production and IgA nephropathy-aberrant mucosal immune response with systemic repercussions. Toxicol Lett 2003; 140-141: 287-95.

[127] Beagley KW, Eldridge $\mathrm{JH}$, Lee $\mathrm{F}$, et al. Interleukins and IgA synthesis. Human and murine interleukin 6 induce high rate IgA secretion in IgA-committed B cells. J Exp Med 1989; 169: 213348.

[128] Yan D, Zhou HR, Brooks KH, Pestka JJ. Potential role for IL-5 and IL-6 in enhanced IgA secretion by Peyer's patch cells isolated from mice acutely exposed to vomitoxin. Toxicology 1997; 122: 145-58.

[129] Shi Y, Pestka JJ. Attenuation of mycotoxin-induced IgA nephropathy by eicosapentaenoic acid in the mouse: dose response and relation to IL-6 expression. J Nutr Biochem 2006; 17: 697-706.

[130] Pinton P, Accensi F, Beauchamp E, et al. Ingestion of deoxynivalenol (DON) contaminated feed alters the pig vaccinal immune responses. Toxicol Lett 2008; 177: 215-22.

[131] Bouhet S, Le Dorze E, Peres S, Fairbrother JM, Oswald IP. Mycotoxin fumonisin B1 selectively down-regulates the basal IL-8 expression in pig intestine: in vivo and in vitro studies. Food Chem Toxicol 2006; 44: 1768-73.

[132] McLaughlin J, Padfield PJ, Burt JP, O'Neill CA. Ochratoxin A increases permeability through tight junctions by removal of specific claudin isoforms. Am J Physiol Cell Physiol 2004; 287: C1412-7.

[133] Sergent T, Dupont I, Jassogne C, et al. CYP1A1 induction and CYP3A4 inhibition by the fungicide imazalil in the human intestinal Caco-2 cells-comparison with other conazole pesticides. Toxicol Lett 2009; 184: 159-68.

[134] Huang C, Jacobson K, Schaller MD. MAP kinases and cell migration. J Cell Sci. 2004 Sep 15;117:4619-28.

[135] Shen L, Black ED, Witkowski ED, Lencer WI, Guerriero V, Schneeberger EE, et al. Myosin light chain phosphorylation regulates barrier function by remodeling tight junction structure. J Cell Sci. 2006;119:2095-106.

[136] Fairhurst S, Marrs TC, Parker HC, Scawin JW, Swanston DW. Acute toxicity of T2 toxin in rats, mice, guinea pigs, and pigeons. Toxiology. 1987; 43:31-49

[137] Ueno Y. Toxicological features of T-2 toxin and related trichothecenes. Fundam Appl Toxicol. 1984, 4:S124-S132.

[138] Pang VF, Lorenzana RM, Beasley VR, Buck WB, Haschek WM. Experimental T-2 toxicosis in swine. III. Morphologic changes following intravascular administration of T-2 toxin. Fundam Appl Toxicol. 1987; 8:298-309

[139] Hayes MA, Schiefer HB. Comparative toxicity of dietary T-2 toxin in rats and mice. J Appl Toxicol. 1982; 2:207-12. 
[140] Harvey RB, Kubena LF, Elissalde MH, Rottinghaus GE, Corrier DE. Administration of ochratoxin A and T-2 toxin to growing swine. Am J Vet Res. 1994; 55:1757-61.

[141] Harvey RB, Kubena LF, Huff WE, Corrier DE, Clark DE, Phillips TD. Effects of aflatoxin, deoxynivalenol, and of aflatoxin, deoxynivalenol, and their combinations in the diets of growing pigs. Am J Vet Res. 1989; 50:602-7.
[142] Pollman DS, Koch BA, Seitz LM, Mohr HE, Kennedy GA. Deoxynivalenol contaminated wheat in swine diets. J Anim Sci. 1985; 60: 239-247.

[143] Trenholm HL, Hamilton RMG, Friend DW, Thompson BK, Hartin KE. -Feeding trials with vomitoxin (deoxynivalenol)-contaminated wheat: effects on swine, poultry and dairy cattle. J Am Vet Med Ass. 1984; 185: 527-531. 